\title{
Notes from the English: Compensation In Town and Country Planning
}

\author{
Daniel R. Mandelker*
}

$\mathrm{P}_{\text {Lanning control both confers benefit and inflicts detriment on land in }}$ Private ownership. A reclassification of farm land to permit industrial development will add substantially to its market value. A variance for a filling station may injure the value of properties in its immediate neighborhood. English planning has long struggled with this twin problem of betterment and compensation - the recoupment for the public of added value conferred by planning, and the compensation of the landowner for restrictions imposed by planning controls. English approaches to this troubled problem have attracted attention for their boldness of concept. To date, however, no satisfactory solution has been achieved, and the present scheme' is more patched than perfect. Nevertheless, this experience is valuable, especially since shifts in American planning require increasingly difficult accommodations between the use of eminent domain and police powers. The English have abandoned the developinent charge, by which they hoped to recover from the landowner for the value added to his property by planning. However, a statutory compensation scheme has been continued. Its analysis may prove instructive for American practice.

\section{I}

\section{POSITIVE PLANNING IN AMERICAN PRACTICE}

Comparison might begin with the more familiar. Full compensation for the taking of land is required by constitution in America. No compensation is payable for restrictions imposed under the police power that meet the test of reasonableness. Difficulties occur when a regulation imposed on land under the police power is allegedly so restrictive that a taking has occurred which requires full compensation.

Public intervention with land use was first accomplished mainly

* Associate Professor of Law, Indiana University. A book by the writer on English Green Belt planning policy is to be published by the University of Wisconsin Press. During 1959-60, the writer was the recipient of a Ford Foundation Law Faculty Fellowship for research in England on English town and country planning. During the year he interviewed national and local government officials, visited several local planning authorities, and talked to lawyers in local government and private practice who specialize in planning law. Much of the material which serves as the basis for this article was secured in interviews and from confidential files. While the use of the material in the form in which it is presented is not thought to violate any confidence, the many persons in government service to whom the writer talked have asked to remain anonymous. At the end of the grant period, during the summer of 1960, the writer served as Legal Adviser on the staff of the East Sussex County Planning Department. 
through public takings under eminent domain. ${ }^{1}$ When the first zoning acts proceeded by way of the police instead of the eminent domain power, a strain was placed on constitutional concepts but court approval was helped by nuisance analogies. ${ }^{2}$ Zoning came in part as an improvement on the common law of nuisance, and at first its function was limited to the separation of incompatible land uses. Separation was usually acconiplished through zoning classifications that protected the "higher" residential and related uses from commercial and industrial intrusions.

Although zoming to separate imcompatible uses may frustrate expectations for development more profitable than that allowed by the ordinance, American planning has characteristically set tolerance limits sufficiently wide to avoid serious limitations on the developer's freedom of choice. But in recent years, American planning has shifted its original objectives. New and less obtrusive methods of industrial and commercial development make the largely negative function of separating incompatible land uses less compelling. Now the planner tends to plan positively. He takes a firmer hand in the shaping of commumity structure, and to implement his plan he may refuse development that otherwise would have been compatible with its surroundings. In making such decisions, he interferes more drastically with the market determination of land use.

A few examples of positive planming will help make this point. Within a developing community, the planner may put a realistic limit on commercial facilities. He may decide that a stretch of highway has been saturated with filling stations. ${ }^{3}$ Or he may attempt to deny a zoning reclassif-

1 But modern land use controls had early predecessors, both in England and in this country. Beuscher, Land Use Controls, ch. 1 (1958). He cites, for example, an ancient English statute which forbids the felling of trees "within four miles of the foot of the hills called the Downs" and in other parts of the realin. Iron-Mill Act, 1581, 23 Eliz. 1, c. 5. The statute exempted the Weald of Sussex and Kent, which then carried an extensive iron industry and depended on wood for fuel. For the modern counterpart see Town and Country Planning Act, 1947, 10 \& 11 Geo. 6, c. $51, \S 28$ (orders for preservation of trees and woodlands).

2 Cf. Hadacheck v. Los Angeles, 239 U.S. 394 (1915).

${ }^{3}$ In Socony Mobil Oil Co. v. Township of Ocean, 56 N.J. Super. 310, 153 A.2d 67 (Super. Ct. 1959), an applicant was denied a special exception that would have allowed him to construct a filling station along a state highway on the ground that the ordinance prohibited the location of a filling station within 1500 feet of another station. There were eleven existing stations in the vicinity of the proposed station. The applicant's lot was clearly within a business district. In sustaining the demal of the application the court relied primarily on the danger to safety from the crowding of stations along a highway. However, the court reported evidence in detail which sought to establish the optimum ratio between population and filling stations, and which suggested that the community was saturated. Compare Cunningham v. Planning Board, 157 N.Y.S.2d 698 (Sup. Ct. 1956), modified on other grounds, 4 App. Div.2d 313, 164 N.Y.S.2d 601 (1957). In that case, a gasoline station was banned from the commercial area of the town on the ground that the community's needs were met by existing stations. The trial court held that this limitation was unreasonable and arbitrary and bore no relation to the public welfare. Apparently the action was both ultra vires and unconstitutional. "The basic economic law of supply and demand and open and fair competition should determine the number of filling stations in this district ...." 157 N.Y.S.2d at 702 . 
cation for a shopping center if it would inpair the success of a previously approved center nearby. ${ }^{4}$

The courts often hold the new positive techniques unconstitutional, perhaps because they depart from the time-honored mold. Positive planning may then be thwarted by judicial balk. These difficulties are particularly apparent on the rural-urban fringe, where positive planning is much needed. For example, new residential construction needs to be timed to keep pace with the developinent of community facilities. Controls of this kind have been imposed indirectly. ${ }^{5}$ On the periphery of a large metropolitan area, one county zoned the outer and little-developed two-thirds of its area for two-acre lots. This restriction confined high density housing to the inner third of the county, closer to the center of the inetropolitan area, where public facilities were adequate. While acreage controls have usually been upheld, in this case the ordinance was held unconstitutional as class zoning. ${ }^{6}$ More direct techniques have been tried, and sometimes approved judicially. One community niay consider the adequacy of existing school facilities when passing on special permits for higher density housing.?

1 Held unconstitutional in Board of County Supervisors v. Davis, 200 Va. 316, 106 S.E.2d 152 (1958). The board refused the rezoning of a tract of 21.37 acres to general business in order to construct a shopping center. Much of the land in the vicinity of the site had been zoned for business. However, the board refused the rezoning because of the adverse economic effect which the new shopping center would have had on another shopping center which had just been authorized on a site which was 1.4 miles away. The board's action was reversed. The restriction of competition and the protection of another enterprise which had been encouraged by a prior zoning classification is not a proper function of zoning. But cf. Shapiro v. Town of Oyster Bay, 211 N.Y.S.2d 414 (Sup. Ct. 1961) (upholds requirement that shopping centers must be more than a mile apart). Compare Kreatchman v. Ramsburg, 224 Md. 209, 167 A.2d 345 (1961) (owner of store in shopping center does not have standing to appeal rezoning for another center 1.5 miles away). See also Bartelt, Shopping Centers and Land Controls, 35 NoTrE DAME LAW. 184, 204 (1960).

5 Fagin, Regulating the Timing of Urban Development, 20 LAW \& ConTEMr. Pros. 298 (1955). But an attempt by one New York town to limit the number of building permits issued each ycar was held to be beyond the powers granted by the enabling act and was characterized as an unconstitutional exercise of power even if authorized. Albrecht Realty Co. v. Town of New Castle, 8 Misc. 2d 255, 167 N.Y.S.2d 843 (Sup. Ct. 1957). Cf. Levitt v. Incorporated Village of Sands Point, 3 Misc. 2d 92, 148 N.Y.S.2d 798, modified on other grounds, 2 App. Div. 2d 688, 152 N.Y.S.2d 711, reargument and appeal denied, 2 App. Div. 2d 781, 154 N.Y.S.2d 842 (1956). In the Levitt case the town attempted to regulate the rate of growth by licensing the sale of homes as a business. Again, the ordinance was held unauthorized.

${ }^{6}$ Board of County Supervisors v. Carper, 200 Va. 653, 107 S.E.2d 390 (1959). The restrictions were adopted by Fairfax County, which is on the outer edge of the Washington, D.C., metropolitan area. The court found that the "practical effect" of the ordinance was to keep "people in the lower income bracket" from living in the western area of the county.

7 Josephs v. Town Board, 24 Misc. 2d 366, 198 N.Y.S.2d 695 (Sup. Ct. 1960). An ordinance which authorized the town board to consider "the problems of providing necessary community facilities," when passing on special permits for residential subdivisions, was held to be within the powers of the zoning enabling act. In this case an application to double the permitted density was denied on the basis that existing school facilities were imadequate. 
Positive steps may also be necessary to control the land wastage that results from scattered, uneven, and undesirable urban growth. A Green Belt may be required-the designation through planning of a reserve of open land which is held in private ownership but which may not be used for urban development. Under a California law, agricultural areas adjacent to urban centers have been zoned exclusively for agricultural uses. Their annexation to a neighboring city is then forbidden except with the consent of the landowners, ${ }^{8}$ although the agricultural classification may easily be changed if the owner so desires. This statute has not yet been tested. Flood plain zoning, which prevents the location of structures in areas of potential flooding along river valleys, has been upheld. ${ }^{\text {? }}$

Professor Allison Dunham has suggested a cost-benefit analysis which would indicate when planning controls may constitutionally be imposed under the police power. ${ }^{19}$ When an incompatible use intrudes into a residential area, it will cast an external cost on neighboring owners by lowering the value of their properties and by creating physical and other disturbances. Public regulation can reduce these external costs by taking into account the effects of interaction in the location of land uses. In cases like this, the restriction may properly be imposed without compensation. But compensation must be paid when the planner shifts his role and plans positively for the location of land uses in order to confer benefits on the public rather than to save external costs to private owners. For example, a regnlation that spaces out new development on the urban fringe to reduce the expense of new public facilities would be compensable because

8 CAL. Gov's Code $\$ 35009$ (Supp. 1960), applied in City of Cupertino v. City of San Jose, 186 Cal. App. 2d 29, 8 Cal. Rptr. 525 (1960). The program is described in Subcommittee on Planning and Zoning, Cahfornia Assembly Interim Counmittee on Conservation, Planning, and Public Works, Preliminary Report on State Green Belt Legislation and the Problem of Urban Encroachment on California Agriculture (1957); Note, 12 Stan. L. Rev. 638 (1960). The California Green Belt differs from most agricultural zoning in that the agricultural use is exclusive and not even residential development is perumitted. In this way the open characteristics of the area are preserved.

9 Vartclas v. Water Resources Comm'n, 146 Conn. 650, 153 A.2d 822 (1959). Following disastrous floods in 1955 , the legislature authorized the commission to establish encroachment lines in flood plains in order to prevent the construction of new structures in areas subject to flooding. In this case, the objector's vacant land fronted a principal street in a town. The commission was upleld in refusing permission to construct a cinder-block building on a concrete foundation within the encroachment line. The court held that the protection of the flood plain was a legitimate exercise of the police power. It also noted that the objector had not applied for an alternate inethod of construction (on piers or cantilevers) which would permit him to make an economic use of his property while at the same time not defeating the purpose of the restriction.

Existing dwellings lying within the encroachment line could be acquired by eminent domain, and the court found no discrimination in the use of the police power over vacant land and the use of the eminent domain power to acquire existing structures. See also Dunham, Flood Control Via the Police Power, 107 U. PA. L. Rev. 1098 (1959).

10 Dunham, A Legal and Economic Basis for City Planning, 58 Corum. L. Rev. 650 (1958). 
it only confers a public benefit. Under this test, most positive zoning would be lield unconstitutional.

Professor Dunham's test suffers from the circumstance that every restriction on land use both reduces costs for adjacent owners and confers benefits on the public. The problem is definitional. If cost is viewed only in terms of the separation of incompatible uses, then the point is clear. The test then ratifies the function of zoning as it was first conceived, and so has an historical bias. Is there any other reason for excluding other costs from the accounting? True, when the planner plans positively to control the pace of development in fringe areas he saves public expense by limiting development to areas where public facilities can more easily and cheaply be provided. He also saves the private landowner from the costs that result from scattered and uneven urban growth, not only in terms of more expensive public facilities, but in terms of the costly effects of a partially developed rural-urban environment. Health may be menaced, for example, if scattered building holds up proper sewers. These costs flow from land use, even though they may be indirect rather than direct. ${ }^{11}$

Furthermore, the cost-benefit approach guides judicial decision-making rather than legislative statute-making. Diffused notions of public use and public purpose in eminent domain combine with expanded concepts of police power and general welfare in planning to confuse the time-lionored distinctions between these two areas. ${ }^{12}$ Conventional judicial analysis has not fully seen the analytical problems which are presented when zoning becomes more positive and, consequently, more restrictive. ${ }^{13}$ When the developinent of land is severely restricted, the impact on the property owner may be almost as serious as when his land is taken from him. Perliaps a legislative adaptation of compensatory eminent domain techniques will be required in these circumstances.

11 Professor Dunham rejects the external costs saved by timing regulations as "specious." See the restatement of his position in Dunham, City Planning: An Analysis of the Content of the Master Plan, 1 J.L. \& Econonncs 170, 182, 183 (1958). But he takes too narrow a view of the objectives sought by this kind of regulation.

See $A$ Critical Look at Zoning Law, Comments of J.H. Beuscher, Mumicipal Law Service Letter, Jan. 1960, p. 7, at 8, col.2: "We may then find that a control that at first sight seems only to confer a public benefit at the expense of the complaining landowner is on second look justified because of costs, relatively hidden, which the landowner's proposed use would impose. ... [Cost-benefit] analysis should be used as a device to uncover factual insights, not as a litmus test of unconstitutionality or constitutionality."

12 See Berman v. Parker, 348 U.S. 26 (1954) (upholding District of Columbia urban renewal law); City of San Antonio v. Pigeonhole Parking of Texas, Inc., 158 Tex. 318, 311 S.W.2d 218 (1958); Williams, Planning Lawe and the Supreme Court: I, 13 Zonive Digest 57 (1961).

13 See Board of County Supervisors v. Davis, 200 Va. 316, 106 S.E.2d 152 (1958), discussed in note 4 supra. The court suggests that the restriction of competition is not the function of zoning. But a comprehensive plan which makes basic decisions on the location of commercial centers and industrial sites will necessarily have a substantial effect on competition. 
Consider the challenge inherent in the planning restrictions outlined above. American practice has so far kept the compensation problem from becoming acute by not limiting too severely the developer's freedom of choice. Residential development has been traditionally residual, so that the owner has never been restricted to the agricultural use of his property. Industrial and commercial development have benefited from municipal over-zoning coupled with lenient amendment and variance practices. ${ }^{14}$ In the examples of positive zoning that have been given, however, restrictions are more severe. Without compensation, the landowner is kept from realizing the full development value of his property for reasons not related to the incompatibility of land uses. Development which is clearly in conformance with surrounding land use is refused for reasons related to larger community goals. A filling station may be turned down just because several others are nearby and the highway is deemed to be saturated. Green Belt farm land which is ideal for residential development may be kept to its existing use to confine urban sprawl. Mixed judicial reactions to these and similar restrictions highlight an underlying question as to the proper statutory basis for these controls. Must the community proceed under eminent domain rather than police power?

II

ENGLISH PLANNING: SHAPING THE COMMUNITY'S WILL

Enghish planning is comprehensive in its scope and direct in its approach. The 1947 planning act, ${ }^{15}$ which is the basic statute, mandates local planning authorities to prepare developnent plans for the entire country. The development plan contains in one document what is usually split in America between the master plan, zoning ordinance, subdivision ordinance, and related legal tools. Unlike the American regulation, how-

14 For examples and a discussion of commercial and industrial over-zoning see Note, 9 U. CHI. L. REv. 477, 488-90 (1942). For statistics on variance administration see ASPO, Planning Advisory Service, Measures of Variance Activity, Information Report No. 60, Marcli 1954.

15 Town and Country Planning Act, 1947, $10 \& 11$ Geo. 6, c. 51. See generally HEAP, AN Outuone of Planneng Law (3d ed.1960); Gamer, Some Aspects of Planning Law in England, 12 U. Toronto L.J. 49 (1957). For discussions published at the time of enactment see FitzGerald, Planning and Development Under the Town and Contntry Planning Act, 1947, 11 MoDERN L. REv. 401 (1948); Monson \& Monson, Development and Practice of British Planning Law, 44 ILL. L. Rev. 779 (1950); Note, 60 HARv. L. Rev. 800 (1947).

Americans may be surprised to learn that English planning was not too effective prior to the 1947 legislation. The principal interwar act was the Town and Country Planning Act, 1932, $22 \& 23 \mathrm{Geo} .5$, c. 48 . It was unsuccessful partly because the procedure for approving planning schemes was too rigid, partly because compensation for "injurious affection" resulting from planning restrictions had to be paid by the local authorities at full market value. 
ever, the development plan is merely advisory. No development ${ }^{16}$ may take place without planning permission having been applied for and received from the local planming authority, and the authority when passing on the application is to consider the development plan and "other material considerations." ${ }^{\prime 17}$ Both the development plan and the individual planning decision are subject to inquiry and review by the Ministry of Housing and Local Government, a national ministry with supervisory powers over local government which has no counterpart in the American states. $^{18}$

English planming differs most from the American in its clear demarcation between town and country, acconipanied by a severe limitation on the size and expansion of the larger towns in favor of the dispersal and decentralization of urban population in smaller communities. ${ }^{19}$ This policy places severe limits on the developer's freedom of choice, and can well serve as a background for the handling of the compensation problem.

Each county is covered by a development plan, and individual plans are prepared in some detail for the larger towns. Town maps embody firm decisions about the size and character of the community. ${ }^{20}$ Outside the town map areas, the planning designation ordinarily is uncolored or "white." 21 This designation means that land uses are to remain as they are for the time being. Only development related to agriculture is per-

16 Town and Country Planning Act, 1947, 10 \& 11 Geo. 6, c. 51, § 12(2) defines development as "the carrying out of building, engineering, mining or other operations in, on, over or under land, or the making of any material change in the use of any buildings or other land." A substantial case Iaw is growing around this section. Cf. Guildford Rural District Council v. Fortescue, [1959] 2 Q.B. 112 (intensification of density may amount to a "material" change in use).

17 Town and Country Planning Act, 1947, $10 \& 11$ Geo. 6, c. 51, § 14(1). By authorizing control of the "development" of land the statute grants a broad-scale power over any substantial changes in land use without regard to possible costs resulting solely from harmful interactions. The councils for counties and county boroughs (usually the larger cities) are designated as the local planning authorities. 1947 Act, $\S 4(1)$. The county boroughs are administratively independent of the county.

18 Town and Country Planning Act, 1947, 10 \& 11 Geo. 6, c. 51, §§ 5, 17.

18 This policy has been of central importance in the planning of the Greater London region, and had its genesis in the Barlow Report. Report of the Royal Commission on the Distribution of the Industrial Population, Card. No. 6153 (1940). For a report on the postwar experience with the Greater London Plan see Report of the Royal Commission on Local Government in Greater London, CarD. No. 1164, at 74-93 (1960).

20 E.g., Administrative County of East Sussex, Development Plan, Survey Report "B"- . Town Map Area No. 10: Written Analysis 24, 25 (May 1960). This survey notes that a certain town is not favored by shoppers and plans its commercial facilities accordingly.

21. For example, with one minor exception, East Sussex has no Green Belt. Therefore, outside the town maps, and on the fringes of the town map areas, the entire county is "white." The effect of this designation is indicated by its development plan statement, which is typical:

9. Within the areas not shown on the County Map by any notation denoting an intended change of use it is the intention that existing uses of land shall remain for the most part undisturbed unless such uses are being carried out in contravention of planning control. All applications under Part III of the [1947] Act for permission to develop within 
mitted in the white areas, with some limited growth permitted in the villages. ${ }^{22}$ When rural control must be firmer, a Green Belt will be used. These are rough-shaped doughnut areas, often several miles wide, which have been placed around the larger cities. ${ }^{23}$ As in the white areas, the rural portions of the Green Belt are limited to agricultural and related uses. Kimship with the California program is clear, although the operation of the English plan is very different. But unlike the white areas, the Green Belts are intended as permanent restrictions. Excess population from the towns compressed by Green Belts is to jump the Belt to selected New Towns and expanded towns beyond the Green Belt ring.

In other areas of control English planning has also been direct. The building of new gasoline filling stations is considerably restricted under a Ministry policy which does not give an absolute value to need but which gives it some recognition. ${ }^{24}$ Apart from the Green Belt, residential building will be limited if not prohibited in areas where new development would endanger the existing water supply. ${ }^{25}$ Advertising signs are subject to strict limitation in the interests of safety and "amenity," though the townscape inay be as cluttered as it is in America, the motorist soon discovers that the billboard is practically extinct in the countryside. ${ }^{27}$

these areas will be considered on their merits.

Administrative County of East Sussex, Development Plan: Written Statement 5 (1958).

A direction to consider applications "on their merits" appears strange to American planners accustomed to working under close delegations. In East Sussex the authority is exercised restrictively to prohibit all but agricultural and allied uses outside the villages. The villages are techmically within the white area but a minimum amount of village growth is permitted under informal local arrangements.

$22 I d$. at $\S \S 7(5), 9$.

23 The present Green Belt program was established by Ministry of Housing and Local Government Circulars Nos. 42 (1955) and 50 (1957). Ministry circulars are issued to planning authorities and to the general public for guidance, and do not have the status of Statutory Instruments.

24 Ministry of Housing and Local Government Circular No. 25 (1958). Section 9 discusses the question of need. "The Minister thinks that to set up a control based entirely on considerations of need . . . would go beyond the proper scope of planning." But where the planning objection is not dispositive, "the question of traffic need can properly be considered; and if no strong case is made out on grounds of traffic need, then the planning objections may beconie decisive." Some indication of the Minister's policy is afforded by his record on appeals. In 1959, out of 427 appeals from local authority refusals of petrol garages, only 53 were allowed and 374 were demed. Report of the Ministry of Housing and Local Government, 1959, CMD. No. 1927 , at $194(1960)$. This success ratio of $12.4 \%$ is substantially below the $30 \%$ average for all cases, a ratio which has beld fairly stable in the last several years.

25 East Sussex Written Statement, supra note 21, at 15.

${ }^{26}$ Town and Country Planning Act, 1947, $10 \& 11$ Geo. 6, c. 51, §31. Amenity, though undefined in the planning acts, is one of the key words in English planning. It means nore than aesthetics, and can be partly defined as the preservation of the barmony of existing uses. Its general thrust is to protect and preserve.

27 Under the advertising regulations, stricter powers unay be exercised in areas of special control, which may include rural areas and other areas "which appear to the Minister to require special protection on grounds of amenity." STAT. INSTR., 1960, No. 695, §10(1). 
Within this framework, the payment of compensation for planning restrictions has assumed more critical proportions. The problem can be summarized as follows:

(1) English planning places restrictive limits on development in inverse proportion to demand. Cities normally grow at their edges. By designating the areas adjacent to cities as Green Belts, the planning system withholds from the market that land which is most ready for residential development. In addition, even though postwar migration figures show a continuing trend to the south where pressures grow more intense, ${ }^{28}$ policies of industrial location favor the depressed north. ${ }^{29}$ By directing development to satellite communities, and to northern urban centers, the English have tried to reverse the normal flow of demand. ${ }^{30}$

(2) English planning functions under an absolute discipline of space. The crowding of fifty million people into an area the size of the State of Wisconsin defies adequate description. Most of southeastern England is one large urban area, and a good bit of the rest of the country is unsuitable for developinent. Residential densities may be higher at the center of some eastern American cities, but they are uniformly higher throughout the English towns and villages than they are in most of the United States. ${ }^{31}$ Noting higher living standards, one observer reinarked that the Englishman would soon be demanding $1 / 10$ of an acre for his suburban house! The southeast is pitted with an intense settlement pattern. Villages occur at intervals of one to three miles, and much of the country in between is filled with ribbon and sporadic development.

(3) Restrictive planning in conjunction with space limitations places severe limits on the developer's freedom of choice. The bite of English planning is well illustrated by an application for industrial development in a medium-sized town in a southeast county. An American industrialist with an English branch wants to construct a new building in order to expand his operations. No plot large enough can be found in the industrial area planned for the town. An industrial building in the residential or nearby "white" area would be out of the question. Expansion of the industrial area is not physically possible and in any event is out of keeping with the population objective for this city. ${ }^{32}$

28 The trend became serious in the period between the first and second World Wars. Attempts to reverse this trend he at the base of much of English planning pohicy.

20 Local Employment Act, 1960, 8 \& 9 Eliz. 2, c. 18.

30 The construction of New Towns, many of them on the periphery of the Greater London area, has been at the heart of this program.

${ }^{31}$ Density figures are difficult to translate. Semi-detached or row housing is common even in the country villages, where single family or detached homes will often be built at five to eight to the acre.

32 This example is taken from an actual case. 
Comparison with the American system is difficult. Constitutionally, no compensation requirement governs English planning law. ${ }^{33}$ By statute, however, compensation has been required. As far as it has gone, American planning has been more ruthless. If development of vacant land for an industrial site is demed under an American zoning ordinance found to pass muster under the constitutional requirement, no compensation will be payable. With sone qualifications, compensation would be payable under the English statute. But the American ordinances until recently have not limited freedom of choice as severely as the English. When they do, the judicial reaction has often been unfavorable, and the regulation has fallen as an iniproper exercise of the police power. ${ }^{34}$ Inaction usually follows an unfavorable decision. American municipalities seldom if ever use the eminent domain power to acquire the land subject to the restriction, and no machinery exists to provide for the payment of compensation without recourse to eminent domain procedure.

${ }^{33}$ See Belfast Corp. v. O.D. Cars, Ltd., [1960] 1 All E.R. 65 (H.L.). Appellant's application to construct industrial and commercial buildings in Belfast was refused because the land was located in an area zoned residential. In terms similar to the Englisl Act, the Northern Ireland planning law excludes compensation for "injurious affection" resulting from planning provisions prescribing the use of buildings. The Minister of Health and Local Government must first find the restriction "reasonable for the purpose." Planning and Housing Act (Northern Ireland), 1931, $21 \& 22$ Geo. 5, c. 12, \& 10(2).

In the Governunent of Ireland Act, which serves as a constitution for the Parliament of Northern Ireland, a clause prolibits the enactment of any law which would "take any property without compensation." Government of Ireland Act, 1920, 10 \& 11 Geo. 5, c. 67, § 5(1). This case thus raises on first impression the equivalent of an American due process issue in the context of a planning regulation.

The court upheld the provisions of the statute which exclude compensation. Two opinions were written. While both opinions recognized that a regulation of land use might be so unreasonable as to constitute a taking, considerable leeway was afforded the legislature. Lord Radcliffe pointed out in dictum that the English Parliament "with its full sovereignty might be able to exclude compensation in cases where the Northern Ireland Parliannent under its constitutional limitations could not." Belfast Corp. v. O.D. Cars, Ltd., supra at 73. Since the English Parliament is not subject to written constitutional limitations, the statement might have been even stronger. Compare the dictum in France Fenwick \& Co. Ltd. v. The King, [1927] 1 K.B. 548,567 , suggesting that in England the common-law right to compensation applies only when possession of the property is actually taken, and not when it is subject to a "negative prohibition."

On the issue of the Minister's power to pass on the reasonableness of the planning regulation, Lord Radcliffe noted: ". . . I do not think that the requirement that compensation can only be excluded if the Ministry concerned passes the restrictions as reasonable for the purpose raises any relevant issue. If compensation could validly be excluded anyway in such cases, the legislative power cannot have been less validly exercised because the town-planning authority's liberty to exclude compensation has been limited by such a provision." Belfast Corp. v, O.D. Cars, Ltd., supra at 74.

34 A survey of the cases discussed in notes 3 3 supra will indicate that the courts have usually reacted unfavorably to direct attempts to interfere positively with land use for reasons not relating to harm-producing interactions. When a favorable decision was reached the court usually found a basis in more conventional safety and related public welfare factors. 
Machinery for the payment of compensation has been provided in two planning acts, passed in 1947 and in 1954. Before this machinery can be described, a related and important point must be emphasized. In England, agricultural land and improvements are exempt from taxation. As a consequence, when agricultural land may not be used for building, the landowner at least is free from property taxes, although he may not be compensated in full. In America, where assessment practices reflect the potential urban use, taxes often skyrocket on farmland that is close to urban development.

\section{III}

\section{COMPENSATION UNDER THE 1947 PLANNING ACT}

\section{A. Introduction}

How the compensation issue has developed can best be understood by beginnimg with its treatment under the 1947 statute, as originally enacted. No owner can develop his land without first receiving permission from the planning authority. This requirement still applies. Under the original scheme of the 1947 law, landowners were to be compensated against any future refusal to develop, and they were to pay the State for the increment in land value if pernnission was granted. These provisions of the law have now been repealed.

An understanding of the original scheme can be gained through an examination of the Third Schedule to the 1947 Act. This Schedule, in two parts, defines the "existing use" of land. It has been reprinted in Appendix A. Its effect can be illustrated by its treatment of existing buildings. Under Part I of the Schedule, existing use is defined to mclude the rebuilding of an existing building, provided the new building does not exceed the original structure by approximately ten per cent. Under Part II of the Schedule, existing use is defined as the "enlargement, inprovement or other alteration" of an existing building, again not to exceed approximately ten per cent of the original structure. ${ }^{35}$

Only the existing use value of land, as defined by the Third Schedule,

35 Definitional problems arising under the Third Schedule are similar to the "structural alteration" limitations which American zoning ordinances place on nonconforming uses. The top two stories of a four-story building were destroyed by enemy action during the second war. The reconstruction of these two stories was held to be a rebuilding within Part $I$ of the Schedule and not an enlargement within Part II. National Provincial Bank, Ltd. v. Portsmouth Corp., 11 Plan. \& Comp. R. 6 (C.A. 1959). This determination, as will be seen, is important to the compensation rights of the landowner. See also Town and Country Planning Act, 1947, 10 \& 11 Geo. 6, c. 51, §112(2) (a), as added by Town and Country Planning Act, 1954, 2 \& 3 Eliz. 2, c. 72, § 71(1); Schedule VII, § 3; Practical Points, No. 806, 1961 J. PIAN. \& Pror. L. 63. For further discussion see Leach, The Third Schedule Right of Rebuilding, 1951 J. PLAN. \& Prop. L. 635 ; Leach, The Third Schedule Rebuilding Tolerance, 1953 J. Plan. \& Prop. I. 530. 
was retained by the owner. The development value of all land in the country was transferred to the State, and this value was defined as the difference between the unrestricted value (for any use) of the land and its restricted value. ${ }^{36}$ Only the uses covered by Schedule III were included in the computation of restricted value. Claims for the loss of development value were to be filed under Part VI of the Act. A once-and-for-all payment was ultimately to be inade on the approved Part VI claims, out of a suin to be appropriated for this purpose.

If permission to develop land were refused, clearly the owner had lost nothing because he had already been compensated for any development value inhering in his land. What if permission to develop were granted? The selling price of the land would be increased by the grant of permission. But since the government had already paid for the development value, it was authorized to collect a development charge equal to the development value, the charge excluding any development comprising an existing use under Schedule III. ${ }^{37}$

Notice that the Third Schedule existing uses were excluded from the definition of development value. The landowner was not compensated for his existing use, nor did he have to pay a development charge for carrying on an existing use. But the Third Schedule uses were "existing" for compensation purposes only. If a newly-proposed Third Schedule use constitutes development, it requires planning permission. A rebuilding of an existing structure is a case in point. What of the unlikely case in which development defined as an existing use under the Third Schedule is refused permission? Section 20 of the 1947 Act, which is still in effect, provides for the payment of compensation by the local authority whenever permission is refused for development falling under Part II of the Schedule. Few claims have arisen under section 20 . What if the planning authority refuses

36 Town and Country Planning Act, 1947, $10 \& 11$ Geo. 6, c. 51, §61. Assume an existing but dilapidated factory structure on the premises. The restricted value would include the Third Schedule rights, which would permit the rebuilding or enlargement of the structure. Take this value as $\$ 50,000$. A value would then have to be placed on the use of the land for any purpose, assuming no planning restrictions existed. These assessments were made on the basis of open market value by government appraisers. If this tract were located in a central business area in which the more intensive utilization of the site would increase its worth, the unrestricted value might be as much as $\$ 100,000$ or $\$ 150,000$. Planning restrictions, however, might prevent the more intense use. The 1947 clain valuations were made before the postwar inflation of land values.

37 Town and Country Planning Act, 1947, 10 \& 11 Geo. 6, c. 51, \$69(2)(a). A proportional development charge was authorized, but in practice the charge was collected in full. The principal white paper leading up to the compensation and betterment features of the 1947 Act is the Expert Committee on Compensation and Betterment Final Report, Cus. No. 6386 (1942) (Uthwatt Report). The history of this development is adequately presented in the references cited in note 15 supra. For a critique of the Uthwatt concepts see Turvey, Development Charges and the Compensation-Betterment Problem, 63 Economrcs J. 299 (1953). 
an application to rebuild, which falls under Part I of the Schedule? The draftsmen were afraid that an absolute right to compensation from the local authority in this case could cripple a plaming scheme which might forbid rebuilding on existing sites.

However, the landowner might force the purchase of his parcel under section 19 of the 1947 Act. This section, which in fact covers more than a refusal to allow a rebuilding, remains in the law as one of the cornerstones of compensation under the town and country planning acts.

The principal provisions of section 19 have been reproduced in Appen$\operatorname{dix} \mathrm{B}$. It authorizes a procedure of reverse eminent domain. The landowner is authorized to serve a purchase notice on the local public authority, ${ }^{38}$ which may or may not be required to buy his property at its full market value. A notice may be served by the landowner wlienever, because of a denial of planming permission, he alleged that his land "has becoine incapable of reasonably beneficial use in its existing state." The local authority may comply or refuse to comply with the notice, ${ }^{39}$ and if they refuse to comply the notice is transmitted to the Minister of Housing and Local Government for his action. He may uphold the authority's refusal, he may confirm the notice against the authority, he may reverse the authority's denial of the initial application for development, or he may grant permission for any other development which would render the property capable of reasonably beneficial use. Before taking any of these actions, the Minister must afford a hearing to any party who requests it.

The discussion that follows evaluates section 19. However, Ministry practice in the reporting of section 19 cases makes an analysis of administrative precedent difficult. Appeals to the Ministry froin refusals to give planning permission are at least officially (though inadequately) reported in annual bulletins, ${ }^{40}$ and the planning and property journals also report a small sample unofficially. ${ }^{11}$ About 10,000 section 19 notices have been served since 1947, and about 90 per cent of these have been confirmed..$^{42}$ Of the rest, only about twenty to fifty go to a hearing annually. In these cases the Minister issues a decision letter, usually based on one of several forms,

38 In the counties, the purchasing authority will not be the planning authority. Planning powers are vested in the counties, but $\$ 19$ directs that the purchase notice be served on the junior municipal governments within the county.

39 This procedure represents a change in practice instituted under the Town and Country Planning Act, 1959, 7 \& 8 Eliz. 2, c. 53. Prior to this change, all notices had to be forwarded to the Minister for his action.

40 Each year the Ministry issues a Bulletin of Selected Planning Appeals. However, these bulletins contain only a minute fraction of the decided cases.

41 Planning decisions are most regularly reported in the Journal of Planning and Property Law, which issues monthly. But not more than five or six decisions are reported each month.

42 Report of the Ministry of Housing and Local Government, 1959, CMD. No. 1027, at 112 (1960). 
which is rather spare in the routine case. Decision letters in section 19 cases are not regularly published, either unofficially or by the Ministry. ${ }^{43}$ Nor have the courts dealt definitively with the critical language of the section. ${ }^{44}$ The discussion is therefore partly speculative, partly the writer's impressions of Ministry policy as it is presently executed.

\section{B. Problems Under Section 19}

The general purpose of section 19 becomes clear when reference is made to the original provisions which the 1947 Act contained for the compulsory acquisition of property by public authorities. Compensation was based on existing use, defined by section $51(2)$ to include any uses carried in Schedule III, for which permission (for compensation purposes) was deenied to be granted. Aside from compulsory acquisition, a denial of permission for an existing use defined by Part I of Schedule III was deemed a tipping point beyond which compensation would possibly be payable under section 19, section 20 having taken care of denials of uses included in Part II.

The statutory background is difficult, but the analogy to American practice is clear. Section 19 functions as reverse eminent domain whenever the exercise of planning powers is deemed to pass the boundaries of reasonableness. American practice, however, does not assume that existing uses are entitled to similar protection. Existing uses that are non-

43 The Minister's 1959 Report, id. at 112, 113, for the first time carries two $\$ 19$ cases. In one case a five-year temporary permission was changed to ten years by the Minister in order to avoid a compensation claim. In the second case permission to convert a disused chapel to a warehouse was refused because the site lay in a good residential area. Alternate commercial or residential uses would have been allowed by the local authority, but the Minister confirmed the claim because he felt that the cost of conversion to any of these proposed uses would be too high.

44 R. v. Minister of Housing and Local Government ex parte Chichester Rural District Council, [1960] 2 All E.R. 407 (Q.B.) is only of limited help. The Minister had confirmed a notice, finding that the land in its existing state was of "substantially less use and value" than it would have been had the apphication for planning permission been granted. This was held to be an error of law. The court said, per Lord Parker, C.J.:

I suppose that, in every case where land is worth developing and permission to develop is refused, the existing use of the land will be of less beneficial use-it will be less useful to the owner-than if it were developed. The test is whether it 'has become incapable of reasonably beneficial use in its existing state'. It may be that the word 'reasonably' invokes some comparison, but the fact that the land is less useful, to use a comprehensive term, in its present state than if developed is clearly not the test. Id. at 409. (Emphasis added.)

Problems arose under an earher form of the section that allows the Minister to authorize alternate uses other than the one refused. R. v. Mmister of Housing and Local Government ex parte Rank Organization, Ltd., [1958] 3 All E.R. 322 (Q.B.) held that the Minister could only authorize alternate uses falling within the Third Schedule. This construction was changed by an amendment in Town and Country Planning Act, 1959, 7 \& 8 Eliz. 2, c. 53, \&35(2), and the Minister is no longer so limited. Problems of procedure on appeal have been largely resolved by the explicit provisions contained in the 1959 Act, $\S 31$ (4) (c). 
conforming live under a death sentence and are supposed to disappear. Under the English scheme, the removal of existing uses calls for the payment of compensation..$^{45}$ As will be seen, furthermore, section 19 is not the equivalent of the due process protection offered under the American constitutions.

Substantial changes have been made in the statutory pattern of the 1947 Act. Development charge was abolished in $1953 .{ }^{46}$ Payment will not be made on the claims filed under Part VI of the 1947 Act, except insofar as the refusal of planming permission attracts compensation under a later planning act passed in 1954. Finally, a 1959 planming law has restored the market price of land as the basis for compensation on compulsory acquisition, including the acquisition of land forced to be acquired under section 19. ${ }^{47}$

In view of these changes, the role of section 19 in the framework of the planning laws has been muddled. It was introduced primarily to provide for the bombed-out site which was marked ultimately for public or other private redevelopment. ${ }^{48}$ Rebuilding by the owner, a Part I existing use, would be refused by the planning authority in the interest of the larger scheme. This section allows the owner to force its earlier acquisition by the public authority. About three-fourths of the cases arising under this section have involved the bonıb damage situation. Statutory history confirms this application. As introduced, the section provided for the acquisition of land which, through the denial of planning permission, had become

45 Town and Country Planning Act, 1947, 10 \& 11 Geo. 6, c. 51, \$\$ 26, 27. Reports to the London County Council indicate the himitations of the purchase approach. In 1956 an estimated 1950 acres of nonconforming industry existed in the County of London. Roughly 450 million dollars would have been required to purchase the acreage considered undesirable, and the county at that time had boosted annual purchases to roughly 750 thousand dollars. Town Planning Committee and Finance Joint Report to London County Council, February 13, February 28, July 9, and September 18, 1956. In the provinces, purchase activity appears to be minimal. The annual agenda for one fringe area county planning authority carried only a few purchase items which could not have exceeded five thousand dollars. See Long, Removal of NonConforming Uses-A Suggestion, 1955 J. PLAN. \& Prop. L. 481, and Leach, Removal of NonConforning UIses, 1955 J. PLAN. \& Prop. L. 559 (replying).

46 Town and Country Planning Act, 1953, 1 \& 2 Eliz. 2, c. 16.

47 Town and Country Planning Act, 1959, 7 \& 8 Eliz. 2, c. 53, pt. 1. Market price was the basis for compulsory acquisition prior to the 1947 law.

48 This explanation was given by the then Minister of Housing and Local Government at the time the 1954 Planning Act was in the Commons. House of Commons, Report of Standing Conmittee $C$ on the Town and Country Planning Bill, 1954, cols. 503-06 [bereinafter cited as H.C. Comni. Rept.]. The Committee report has no exact American equivalent, and consists of a verbatim transcript of the committee's discussion of the bill. Committee inembers also debate amendments to the bill, which are proposed by way of a formal motion. In the House of Lords there are no separate committees, but the House convenes as a committee for the consideration of the bill. As the 1954 Planning Act added a clarifying clause to $\$ 19$, it was the occasion for debate on the interpretation of this section. English courts will not look at legislative history, but American readers may be interested nonetheless. 
"incapable of reasonably beneficial use in its existing state [of development, whether by reason of the deterioration or obsolescence of buildings or the occurrence of war damage or otherwise.]" To avoid the application of ejusdem generis to the "or otherwise" clause, all of the language in brackets was dropped. ${ }^{49}$ The result is to make the clause capable of indefimite extension to situations beyond the original legislative intent.

The crucial interpretive problem under section 19, and the one most enticing to an American lawyer, is the scope of "reasonably beneficial use." Clause $2 \mathrm{~A}$ of section 19 provides additional clarification. ${ }^{50}$ When determining the reasonably beneficial use of land, "no account shall be taken of any prospective use of that land which would involve the carrying out of development of any class not specified in the Third Schedule to this Act." This clause himits the comparability of English and American compensation methods, because each starts with different basic assumptions. Potential prospective use of land is a factor to be considered in passing on the constitutionality of American zoning ordinances. Clause $2 \mathrm{~A}$ means that the denial of reasonably beneficial use is to be determined first by starting with the land in its existing state. Existing state must be distinguished from existing use. Existing state means any use of the land for which planning permission is not required. ${ }^{51}$ This state is to be compared

49149 H.L. DEB. (5th ser.) 603, 604 (1947) (in committee). There was no other debate on $\$ 19$ at the time the 1947 Act was passed. Note that obsolete and deteriorated structures would in all probability be marked for demolition as part of a redevelopment scheme.

50 This clause was added to $\S 19$ by the Town and Country Planming Act, 1954, 2 \& 3 Eliz. 2, c. 72, § 70. This clause was clarified by an amendment in the 1959 Act, $\S 35$. See the discussion in note 44 supra.

51 The statutory distinctions are not easy. Any use presently being made of the property would be included within the plurase "existing state." But any other "existing use" contained within the Third Schedule to the 1947 Act would not be included, because these uses are "existing" for compensation purposes only, and still require planning permission. The use of land in its existing state will also include any development, such as an immaterial change of use under the 1947 Act, $\$ 12$, which does not require planning permission.

Reference may also be made to the 1947 Act, $\$ 19(1)(b)$, which provides for the payment of compensation whenever land cannot be rendered capable of reasonably beneficial use through the carrying out of any conditions which are attached to a planning consent. For sinplicity of presentation, these cases have been eliminated from this study.

Finally, $\$ 19(1)$ (c) provides for the payment of compensation whenever land cannot be rendered capable of a reasonably beneficial use "by the carrying out of any other development for which permission ... is deemed to be granted ...." Provision has been made for several classes of minor development, for which no application need be made and for which development is deemed to be granted. General Developinent Order, [1950] 2 STAT. INSTR. 1051 (No. 728), as amended, [1958] 2 STAT. Instr. 2328 (No. 1460); STAT. InsTR., 1960, No. 238. The Minister has also scheduled several classes of land use, and changes nay be made within each use class without applying for permission. Use Classes Order, [1950] 2 Star. INsTR. 1097 (No. 1131), as amended, Stat. Instr., 1960, Nos. 282, 1761. See Leach, Purchase Notices, 1960 J. Plan. \& Prop. L. 78, 83. In deciding whether to confirm a $\$ 19$ notice, reference will be had to any deemed devclopment even thongl not applied for, to determine whether a reasonably beneficial use can be made of the land. 
with all other uses (1) which constitute development requiring planning permission but (2) which are limited to the existing uses contained in the Third Sclıedule. The Third Schedule uses, it will be remembered, still require planning permission.

An example will illustrate: $X$ owns an apartment building in a blighted section of a town. The building burns. $X$ applies for planning permission to rebuild the apartment but is refused because the public authority contemplates the redevelopment of the entire area. If he serves a section 19 notice its confirmation by the Ministry, should the local authority refuse to purchase, would be a foregone conclusion. Two steps are involved in reaching this result. First, the existing state of the land is compared with the Schedule III uses to determine if a scheduled use is denied the landowner. Since rebuilding is a scheduled use and lias been denied, this part of the requirement lias been met. Second, is the land then capable of "reasonably beneficial" use in its existing state? A vacant parcel in a residential area has few if any alternate uses. Of course, it might be used for parking or for lome gardening. But the Ministry is apparently not prepared to treat these "open" uses as "reasonably beneficial" in an urban area.

Even so, this simple example raises difficult problems. What is the test for determiming reasonableness? Is it the plrysical adaptability of the land? Is it the economic return which can be had on the land? Is the relation of the property to its surrounding environment of any importance? Conceivably, and in spite of clause $2 \mathrm{~A}$, the prospective use of land beyond the Third Scliedule categories can slip into a determination of reasonableness if environmental conditions can be considered. ${ }^{52}$

To change the example just given, suppose a burned-out commercial building in a blighted area. The owner proposes a rebuilding for industrial purposes. No comparison may now be made between the existing state of the land and its proposed use for industrial purposes, because the rebuilding will require a inaterial change in use and is not within the Third Schedule. ${ }^{53}$ But the reasonableness of the use in the land's existing state must still be determined.

52 See the discussion in note 54 infra.

63 This conclusion follows from the 1947 Act, Third Schedule, $\$ 6$. That section includes within "existing use" only a change in use which falls within a Use Classes Order, made for the purposes of the Third Schedule, but which is similar to the Use Classes Order cited in note 51 supra. Practically all changes from one use class to another would comprise a material change in use and therefore would constitute development requiring planning permission. The Use Classes Order for Third Schedule Purposes is [1948] 1 STat. Instr. 4231 (No. 955). Unlike the general Use Classes Order, it cannot be amended. Town and Country Planning Act, 1947, 10 \& 11, Geo. 6, c. 51, §111(4). As an example, each Order sets up three industrial groups, combining in each group related industrial uses. A transfer from one use to another, within each group, would not require planning permission. 
Section 19 can most profitably be examined in light of the Green Belt policy, since this policy parallels American experiments in which the positive direction of land use for wider community purposes has severely limited the developer's freedom of choice. Wliat is the position of the landowner if his farm or other open land in the Green Belt is restricted from urban development? Several types of cases will be examined, each of which presents compensation problems that have arisen in Green Belt or other rural areas where planning control has been restrictive.

\section{Ministry Policy Under Section 19 in Green Belt Cases}

(1) Use in existing state inhibited by individual hardship. Small parcels are commonly found in the English countryside which are ill-adapted for agricultural use because of location or the coincidence of legal ownership. In some instances a farmer may sell off a corner parcel for a housing development. If the purchaser's application to build is refused, he may be left with a piece of land that is unusable. He might possibly lease it to a neighboring farmer for grazing purposes, or to local residents for market gardens. But if the original owner was willing to sell in the first place the possibility for agricultural use in the neighborhood may be slight. Other farmers, for example, might face difficulties of access.

Sometimes the owner's plight may not be self-inflicted. The severance of the parcel may have antecedents that are lost to memory, or the plot may be left over following public housing or other local public authority development. The Ministry's position in these instances is to ignore the circumstance of legal ownership. Its test is physical. In a Green Belt, the residual use is agricultural. If the plot is capable of agricultural use, even though its present ownership prevents that use, the section 19 notice will not be confirmed. ${ }^{54}$

54 Clause $2 \mathrm{~A}$ was added to $\S 19$ by the 1954 Act because of interpretative difficulties which had arisen. In committee discussion in the House of Commons the Minister of Housing was asked whether owners of land restricted from development in the Green Belt could successfully serve purchase notices under $\$ 19$. In reply, the Minister reviewed the history of the section and indicated that $\S 19$ would not apply because ordinarily the land would have been farmed prior to the application, and farming could continue after the refusal. He adnitted that the section would apply in the case of a small field that had been rendered useless by nearby development. He referred to an amendment which would be introduced, to insure that the Minister would not have regard to any development outside the existing use range. The reference is to clause $2 \mathrm{~A}$.

Then the Minister stumbled. He stated that $\$ 19$ operates when the landowner cannot enjoy a previously existing use of the land. He was then asked whether $\$ 19$ could be invoked only when land could not be put to its existing use. If so, this would change the law, presumably because the test is whether the land is capable of reasonably beneficial use in its existing state. In reply, the Minister said that the interpretation of $\S 19$ would not be changed from what it was previously. The discussion raises but does not resolve the ambiguitics in the section. H.C. Comm. Rept., note 48 supra, cols. 502-10.

These points were again raised in the debate on the floor of the House of Commons. One 
Some merit lies in the Mimistry position whenever the claimant has purchased subsequent to the imposition of the Green Belt restriction and therefore at least with constructive knowledge of the risks involved. ${ }^{55}$ The statute requires that the land "become" incapable of a use that is not reasonably beneficial, and arguably it has "become" this way because of the owner's calculated risk-taking with the possibilities of securing permission to develop. ${ }^{56}$ Otherwise, this interpretation appears unduly restrictive. Nothing in the statute restricts the Ministry solely to a consideration of physical adaptability.

(2) Use in existing state physically impossible. When land is not physically capable of raising crops, and its use in the Green Belt for other purposes is refused, a purchase notice will be confirmed. Physical subsidence from minimg or flooding is an example. These cases fall clearly within the ambit of section 19.

(3) Use in existing state requires prohibitive capital investment. In some cases the use of the property in its existing state may require a prohibitive capital investment. ${ }^{57}$ Farming requires continuous capital renewal as any industry. Machinery and buildings may need replacement or extensive repairs. Another example is the nursery for growing cut flowers. Greenlouses and other equipment may need replacement in order to keep the nursery competitive.

member contended that there would be no denial of reasonably beneficial use if Green Belt land subject to an application had previously been farmed. Another member noted that clause 2A attempted to end the argument that the reasonably beneficial use must be related to the development for which permission was refused. But he noted that the section was still vague. In closing, the Minister of Housing coneluded that Green Belt land would not lave to be bought under $\S 19$. This would be "impossible." 530 H.C. DeB. (5th ser.) cols. 330-38 (1954).

55 See Practical Points, No. 641, 1957 J. Plan. \& Prop. L. 223. Another example worthy of note occurs in Peacehaven, an interwar coastal residential development in East Sussex. Americans would call it a premature subdivision-an area laid out in small lots which has been sporadically developed. The English word is plotland. In order to provide for the more orderly development of the area, the planning authority is prohibiting development at the outer edges until the inner core is completed. Purchase notices have been served when development on a lot lias been refused, on the ground that the tract is so sinall that any other use but residential is not feasible. Conflicting statements have been made to the writer, but the Minister appears to refuse the notice except when the local authority plans to buy the lot for public use. English policy toward this area typically reflects a determination to regulate growth in order to prevent land waste.

56 In other cases a residential subdivision developer may have reserved an area for open space. When the development is completed he may apply to put houses on the open land, and when refused serve a $\$ 19$ notice. He may elaim that the open area, surrounded as it is by houses, cannot be put to any reasonably beneficial use. These notices are refused on the ground that the open space is reasonably beneficial to the entire subdivision. Analogies may be drawn to the American practice in some communities of requiring the developer to dedicate parks and open spaces without compensation.

57 The Ministry las recognized that the need for a prohibitive capital investment may be a factor leading to the acceptance of a $\$ 19$ notice. See note 43 supra. 
Assume that an application to build houses has been refused under the Green Belt policy, and that the owner serves a section 19 notice that is refused by the local authority. Once more the Ministry would apply a physical test. The purchase notice would be confirmed only if the additional investment were needed to improve the quality of the soil or if the venture were a new one. If the business were already established, the notice would not be confirmed. Only compassion for difficult circunnstances distinguishes the treatment of the new from the established entrepreneur. Potential rate of return froin the use of land in its existing state is a factor considered by American courts when passing on the propriety of a zoning variance or a zoning amendment. Since section 19 requires that the land be capable of reasonably beneficial use in its existing "state," a requirement that the owner make a prohibitive capital investment to improve that "state" arguably goes beyond the language of the statute.

(4) Use in existing state obsolete. Often an existing building may still have a useful physical hife not requiring additional capital investment, but nevertheless may be rendered obsolete by changing tastes and requirements. A recurring case involves the large Victorian house, which is comInon in suburban areas. Quite often the Green Belt will wash over a developed suburban area, or even an entire small town or village whose growth is meant to be restricted. Out of fear of increasing densities, the planming authority will refuse an application to convert a large home to flats or, more frequently than not, to tear it down and build several bungalows in its place.

If his application is refused the owner may be stuck with a white elephant. He may not have the income to run it, and he will no doubt find that his property has a very low market value. Similar problems have arisen in the case of disused movie theaters and other business structures. The planning authority may have decided that the character of the surrounding area needs changing and so will deny an application for conversion to another commercial use. Occasionally the theater will have been located "before planning" in a residential area.

In these instances the Ministry, as is so often the case in planning matters, will decide the apphication "on the facts." However, the tendency is to confirm the notice. Sometines other cumulative factors may contribute to the decision. Permission may well have been granted to convert to another use, but the owner may allege that the capital investment is prohibitive. Or the building may be near the end of its useful life. ${ }^{58}$ These cases have an American counterpart in the nonconforming use. An existing structure possessing a use contrary to that permitted by the zoning

58 See Green v. Birmingham Corp., 2 Plan \& Comp. R. 229 (Lands Tribunal 1950) (assumes $\$ 19$ notice would be confirmed in such a case). 
ordinance is permitted to continue and even to make a change within the same use class, unless compensation is paid for its removal..$^{59}$ On the other hand, the zoning ordinance may apply retroactively to a vacant tract that is undeveloped. By concentrating on existing use rather than on existing investment in structure, section 19 does not distinguish as nicely between the equities in the landowner's position. But the tendency to compensate the landowner left with an unusable structure, and not to compensate the landowner left with an unusable vacant tract of land, comes closer to the American practice. ${ }^{60}$

(5) Use in existing state inhibited by change in environment. Around those cities selected for restriction, Green Belts are supposed to hold the urban fringe against further urban development. Planning boundaries nust always make compromises, however, and farniers located on the outer urban periphery may find their farming operations affected by nearby residential uses. ${ }^{11}$ Nor can the Green Belt always be held at all costs. Exceptions are allowed, and a peripheral farm may find itself slowly surrounded by residential developnient.

This type of case is perhaps most difficult to handle. Consider a hypothetical problem: Farmer Jones has a farm which is substantially surrounded by residential development. As a result, dogs bother the livestock; children trample the fields. In the normal course of events, Jones must make replacements in his capital equipment. But he hesitates. In view of the recent development of the area for residential uses, he wonders about his farming future.

When Jones reaches the point at which the burden of trespass and the need for capital replacement make farming unprofitable, he may well apply for permission to grow houses instead of oats on his acres. If he is refused because of Green Belt policy, can he compel the purchase of his property? Unless the physical encroachment on the farm is serious and substantial, so as to make farming difficult if not impossible, the notice will not be confirmed. No account will be taken of intangible, environmental factors.

The Ministry's position on economic rate of return can be illustrated by a similar though tougher case. Confirmation of a notice was denied on

59 The point is much mooted. While the extension, repair, and structural alteration of nonconforming structures is usually prohibited under the American ordinances, the imterpretation of these provisions has created difficulties. Cf. Cole v. City of Battle Creek, 298 Mich. 98, 298 N.W. 466 (1941); Mandelker, Prolonging the Nonconforming Use: Judicial Restriction of the Power to Zone in Iowa, 8 DRAKE L. REv. 23, 24, 25 (1958).

${ }^{60}$ Similar distinctions will appear in the compensation provisions of the 1954 Act.

11 See Bradbury, The Geometry of Urban Expansion, $40 \mathrm{~J}$. Town Planndng Institute 106 (1954); Planned Urban Development and Its Effect on Agriculture, $39 \mathrm{~J}$. Town Planning INSTITUTE 234 (1953). 
a rough piece of land lying outside a town. The land could be used for rough grazing, and this was held to be a reasonably beneficial use even though the rate of economic return was low.

(6) Use in existing state inhibited by planning blight. A final problem which arises under section 19 is related to the power of compulsory acquisition. Under section 5(2) of the 1947 statute, the development plan may "designate" private land which is subject to future compulsory acquisition by public authorities. ${ }^{62}$ In addition, the written statement may list other proposals for public improveinents, such as schools and highways. ${ }^{03}$ Naturally, land affected by designation or by the written allocation may prove difficult to sell on the open market. "Planning blight" is then said to have occurred. Part IV of the 1959 Planning Act permits the landowner to compel public purchase in many of these cases, provided reasonable efforts have been made to sell the land and the price offered does not meet reasonable expectations. ${ }^{64}$

Even the 1959 law leaves untouched many situations related to compulsory acquisition. One case, common in America since the initiation of limited access highways, involves the roadside inn or cafe which loses most of its trade when traffic leaves the old road for the new. Practically all attempts in American jurisdictions to claim compensation for consequential damages in eminent domain have failed in cases like this. ${ }^{05}$ The English Ministry is likewise reluctant to confirm section 19 notices in such cases, but would do so if the enterprise were practically put out of business. A similar case might arise in England when local public housing bites into a farm and leaves an unworkable unit. If the remainder of the farm is in the Green Belt, planning permission might be refused for private developinent even though public housing was allowed. ${ }^{06}$ Cases like

${ }^{62}$ See also [1948] i Stat. Instr. 4179 (No. 1767, § 8) (designation map is part of development plan); Heap, Development Plans: Designation or Allocation of Land, 1951 J. Pran. \& Prop. L. 629.

03 Mmister of Housing and Local Government Circular No. 54, § 14 (1959).

64 Town and Country Planning Act, 1959, 7 \& 8 Eliz. 2, c. 53, § 39. The 1947 Act, § 9, in any event puts a twelve-year limit on the designation, and after that date the local authority can be required to purchase the land. See Heap, Planning Blight, 1961 J. PLAN. \& Prop. L. 507.

65 For representative cases on this and related situations see People ex rel. Dep't of Public Works v. Symons, 54 Cal.2d 855, 357 P.2d 451, 9 Cal. Rptr. 363 (1960) ; Riddle v. State Highway Comm'n, 184 Kan. 603, 339 P.2d 301 (1959); Carney v. Mississippi State Highway Comm'n, 233 Miss. 598, 103 So. 2d 413 (1958); Good Deal of Ivy Hill, Inc. v. City of Newark, 56 N.J. Super. 124, 151 A.2d 584 (Super. Ct. 1959) ; Walker v. State, 48 Wash. 2d 587, 295 P.2d 328 (1956). See also Note, Freeways and the Rights of Abutting Owners, 3 StAN. L. REv. 298 (1951) ; Note, 42 MinN. L. REv. 106 (1957).

${ }^{66}$ In one planning appeal heard by the writer a farm had slowly been eaten away. The farm was adjacent to a small village and bounded by a secondary highway. Part of the farm had been acquired for local public housing. Private development had been allowed along a strip on another edge of the farm in order to complete the other side of a village street and 
these are similar to those in which the farm is surrounded by development, or in which a decrease in the size of the farm requires new capital investment and a new kind of farming. Again, so long as some kind of farming on the land is practicable, the Ministry will not confirm; it will not take account of the local authority's own building policies. ${ }^{67}$

A different form of planning blight, not strictly within the meaning of the term as usually understood in England but nonetheless related, occurs when a fringe area is programmed. The 1947 Act permits planning authorities to program the order of residential and other development, so that ribbon and sporadic development can be avoided and the provision of new services can keep pace with the provision of new housing. ${ }^{68}$ Wedges of programmed land may abut on the Green Belt. White areas must also be considered. These have been defined as areas subject to no designation, in which uses are for the time being to remain as they are. White areas may be wedged between the developed portion of a town and its Green Belt, as a safety zone for possible development. ${ }^{69}$ When planning permission is refused in a white area, or in an area which has been programmed for development in a later period, the landowner may serve a section 19 notice. Has he been denied the reasonably beneficial use of his land if his realization of its full development value has been postponed

permit the paving of the street to urban specifications. In this appeal the owner of the farm claimed that farming on the remaining portion was unprofitable unless he turned to intensive hvestock raising, which would be offensive to his neighbors. Furthermore, the farm needed modernizing. Permission to build houses had been refused by the planning authority because the farm was located in an unofficial Green Belt. On appeal, the authority was upheld, but on the ground that to allow additional development would be an unjustified extension of the village. "The site also contributed to the general rural character of the locality .... [and] should be included in the proposed green belt."

07 Two examples may be given of instances in built-up areas in which planning blight can occur although the local authority does not plan to acquire the property. (1) The property is dilapidated or unsafe and is subject to a demolition order; (2) the property is subject to a counprehensive redevelopment scheme but is not expected to be publicly acquired. In both cases the ultimate destruction or change in use of the property will be postponed for an indefinite period. See Owen v. Bolton Corp., 12 Plan. \& Counp. R. 97 (Lands Tribunal 1960) : Forced purchase under the 1959 Act is possible only when the land is allocated directly for purposes of the local authority. In the case of an allocation for redevelopinent the practical consequences must be considered. An area containing 6393 people would require the exercise of functions by the local authority in view of the scope of the undertaking, even though private redevelopment would be possible in theory.

68 Town and Country Planning Act, 1947, 10 \& 11 Geo. 6, c. 51, § 5(1); [1948] 1 SraT. INSTR. 4180 (No. 1767, § 12), as amended, [1954] 2 StAT. INSTR. 2412 (No. 933, § 6); [1959] 2 STAT. INSTR. 2623 (No. 1581, §6).

69 As described in Minister of Housing and local Government Circular No. 50 (1957), white areas lying between the town and the Green Belt are contemplated as a hedge agamst possible mistakes in houndary and pohicy-making for the enclosed town. One planning officer feels quite strongly that white areas in this situation are at best an uneducated guess with no real planning basis. He feels that you either run a policy of restriction or that you don't. His belted towns have no white areas. 
for a period of time, either definite or indefinite? This is a difficult question with which the Ministry is still strugghing.

\section{An Evaluation of Section $19^{70}$}

Section 19 has not filled the place in English planning law which potentially it night occupy. English lawyers have not thought of it as a catch-all compensation remedy, and so have not pushed the section to its limits. In addition, a successful section 19 claimant, prior to 1959 , would not have been paid the full narket value of his property. Since the 1959 Act, market value must be paid on all acquisitions, and the experience under that act has not been sufficient to indicate whether a greater use will now be made of section 19.

A second difficulty inheres in the language of the statute, which experience has not yet fully clarified. One of the most troublesome constructional questions is whether the prospective use for which planming permission was denied has an impact on the section 19 determination. Clause $2 \mathrm{~A}$ precludes taking account of the prospective use. Often, however, the prospective use reflects environmental and market factors, which conceivably can creep back into the determination of what is reasonably beneficial. ${ }^{71}$ At least in the Green Belt cases, the Ministry ignores any but physical circumstances and refuses the notice provided some minimal economic use can be made of the land. This policy is bent only occasionally by compassionate circumstances when the use of the land is almost totally restricted.

Whether the Ministry's interpretation is correct must await court decision. While free-floating American concepts of "policy" could be applied to achieve a workable result, English courts are decidedly literal-minded even when dealing with public law questions. ${ }^{72}$ They will undoubtedly work from the four corners of the statutory language. That this language is not clear has been demonstrated, however. ${ }^{73}$

The basic character of section 19 lies in its distinction between a reasonably beneficial use of land and a reasonably beneficial restriction of land. Under the statute, a planning restriction may be compensable regardless

70 No assessment has been attempted of the practical problems involved in operating $\S 19$. Some authorities claim that the forced purchase of scattered and isolated sites throughout the commurity has left them with unusable properties whose maintenance then becomes a burden on the taxpayer. But if the decision has been made to compensate for the imposition of onerous planning restrictions, this expense and inconvenience becomes one of the necessary costs of planning. Over a period of time, the isolated parcel can perhaps be harmonized with surround. ing uses and then sold off or put to more beneficial public purposes.

71 See Francis, Operation of the Town and Country Planning Act, 1954, 42 J. Town Pranning Institute 60, 63 (1956); Leach, Purchase Notices, 1959 J. PinN. \& Prop. L. 88.

72 See Davis, The Future of Judge-Made Public Law in England: A Problem of Practical Jurisprudence, 61 CoLUM. L. REv. 201 (1961).

${ }^{73}$ See text at note 50 supra. 
of its potential benefit. Thus, the section concentrates on the impact of the restriction on the use of the property. This focus emphasizes the greater restrictions which English plannimg places on the development of land. At the same time it leaves out of account a consideration of the reasonableness of the planning regulation, a component which is part of the American inquiry into the constitutionality of land use controls.

Under the original law, compensation for the compulsory acquisition of land was in any event himited to existing use value. This was true if a section 19 notice was confirmed. For this reason, there was inferential support for an original interpretation which would have made the section applicable on a discretionary basis to the demal of an application for development coming withm Part I of Schedule III. ${ }^{74}$ However, section 19 is not so worded. While clause $2 \mathrm{~A}$ discounts any prospective development of the land subject to the notice, the 1959 planning laws' restoration of market value as the price for compulsory acquisition distorts the original statutory intent and makes problematical the position of section 19 in the present structure of the planning laws.

\section{IV}

COMPENSATION UNDER THE 1954 PLANNING ACT

\section{A. Introduction}

Parliament, it will be remembered, abolished the development charge in 1953 and at the same time abandoned the once-and-for-all payment of compensation for the development value of land. When the development charge was abolished, the development value of land was returned to its owner. If he receives permission to develop, he may now keep for himself the full increment to the value of his land that the grant of permission confers. Having abolished the development charge, Parliament might have decided that a fair solution would have eliminated any provision for the compensation of the landowner as well. Instead, Parliament in 1954 enacted a planning law ${ }^{75}$ which supplants the once-and-for-all payment proposed under the 1947 statute with provisions for the payment of compensation for individual planning refusals as they occur. ${ }^{78}$

74 See text at note 37 supra.

75 Town and Country Planning Act, 1954, 2 \& 3 Eliz. 2, c. 72. See generally KeRRIGAN \& Jarnes, The Town and Country Pianding Acx, 1954 (1955); Lawrance \& Wuite, A Gume to tere Town and Countrx Planning Act, 1954 (1955); Leach, Planning and Comprensation LAW (1956); Heap, Compensation for Planning-The Illusion and the Reality, 1954 J. PLAN. \& Prop. L. 316; Heap, The New Town and Country Planning Act-1954 and After, $1955 \mathrm{~J}$. PlaA. \& Prop. L. 5, 100, 180.

76 For criticisms of this approach see Expert Committee on Compensation and Betterment, Final Report, Carb. No. 6386, at 21, 22, 55, 56 (1942) (Uthwatt Report). The Report was influenced by the experience under the 1932 Act, when the payment of compensation for plan- 
Compensation is payable under the 1954 law only when permission has been demied for "new development," "77 and it is recoverable by the government if "new development" is finally permitted. ${ }^{78}$ Again, the key to compensation lies in the Third Schedule to the 1947 Act. "New development" is defined as any development other than development included within the Third Schedule. Unlike the section 19 notice, the 1954 Act claim is filed with and paid by the national government. The claimant must have an outstanding claim for loss of development value, filed under the 1947 Act, and which has not been paid. ${ }^{79}$ As in the case of section 19, the Ministry may allow an alternative development or the development applied for by the applicant, in which case the claim will be denied. ${ }^{80}$ Applications for payment under the 1954 law are made on standard forms. ${ }^{81}$ No hearings are provided, and no decision letters are issued. Any discussion of the claim between the Ministry and the applicant is informal..$^{82}$ An appeal lies to the Lands Tribunal, an administrative tribunal with appellate jurisdiction over compensation questions.

The requirement that the claimant must have filed under the 1947 statute places a practical limit on the effect of the 1954 provisions and is its most distinguishing characteristic. First, some landowners may not

ning restictions at anarket value had had a serious inbibiting effect on planning. The Report inferred that the amount of compensation payable would have to be controlled. But the Report agreed that compensation would have to be paid for permanent restrictions on land use and suggested that the Minister be given a discretion to determine the amount of compensation payable. Id. at 96.

77 Town and Country Planning Act, 1954, 2 \& 3 Eliz, 2, c. 72, § 16(5).

78 Town and Country Planning Act, 1954, 2 \& 3 Ehz. 2, c. 72, \$29(1). "No person shall carry out any new developinent to which this section apphes ... until such amount (if any) as is recoverable under this section in respect of the compensation specified in the notice has been paid or secured to the satisfaction of the Minister." The notice referred to is the notice of the amount of compensation paid, which is to be recorded in a local Land Charges Register. 1954 Act, $\S \S 28(4), 28(5)$. Section $29(4)$ authorizes the Minister to remit all or part of the amount recoverable if otherwise "no such development is likely to be carried out ...."

79 Town and Country Planning Act, 1954, 2 \& 3 Eliz. 2, c. 72, §\$ 17-19. The statutory provisions are shightly more complex. The land must have an "unexpended balance of established development value." This means that a claim inust have been filed and accepted under the provisions of the 1947 Act. The balance may be reduced either by a part payment of the claim or by "new developnient" attributable to the land.

80 Town and Country Planning Act, 1954, 2 \& 3 Eliz. 2, c. 72, §§ 23, 24. See also $\S 21$, which provides that compensation will not be payable whenever permission is available for "any development of a residential, commercial or industrial character ...." The purpose of this section is to limit the landowner to a reasonable return on the use of his land. Notes on Clauses, Town and Country Planning Bill, 1954, at 43, [herinafter cited as Notes on Clauses].

81 The making of a clain is required by $\$ 22(1)$. The form of the claim is contained in a schedule to the Town and Country Planning (Compensation) Regulations, [1954] 2 STAT. INSTR. 2404 (No. 1600). It merely requires hasic information as to the description of the property, the name of the applicant, the reference to the planning decision, etc.

82 Except for informal correspondence, the Minister's decision is given on standard forms. 
have filed claims under the 1947 provisions. Apart from instances of neglect, the pace of development since 1947 may have attracted development value to areas which then were thought to be devoid of value. ${ }^{83}$ Second, the amount of payment is limited to the 1947 Act claim. This limitation places a low ceiling on compensation. Land values have tripled and quadrupled since the claim date and the claim may represent a small fraction of market value. As a consequence, difficult payment and valuation problems which might have been presented by a wholesale attempt to compensate for planning restrictions have been avoided. ${ }^{84}$

Finally, the restriction of 1954 Act compensation to 1947 Act claimants gives the program a transient cast. Ultimately, all of the claims made under the 1947 Act could be expected to be paid out. Experience so far indicates, however, that the process may take longer than was expected. In the first five years of the 1954 Planning Act, only about eight per cent of all claims made were refused, but the claims paid represent only about eight per cent of the total value of claims outstanding. ${ }^{85}$ In many cases, claims were only made following a change in ownership, as on the death of the original claimant. This experience indicates either that landowners are satisfied with the existing use of their land, or that land on which claims have been filed has been developed or is expected to be developed. ${ }^{86}$ Or

83 See the comment by Desmond Donnelly, M.P., at 525 H.C. DEB. (5th ser.) 99 (1954).

84 Section 26 of the 1954 Act defines the measure of compensation. The value of the land without the planning permission applied for is to be compared with the value of the land if the planning decision "had been a decision to the contrary effect." Value without permission is to include any development included in the Third Schedule of the 1947 Act. Value as if the decision had been to the contrary is to include any conditions under $\S 20(2)$ of the 1954 Act which the planning authority might reasonably have imposed. The conditions falling within $\$ 20(2)$ are those for which compensation is excluded. See text at note 90 infra.

What if the owner of isolated waste land in the Green Belt applies for planning permission for commercial use? Obviously, no developer would think of building shops in such a location. However, when the application is refused, § 26 mandates that compensation be awarded as if the application had been granted. Therefore, theoretically the claimant can maximize his compensation by applying for the most renumerative, though patently nonsensical, use. This contingency has not created difficulties, however, since compensation is limited by the 1947 claim, which is much below current market values. Besides, the true development potentiahty would have been considered when the 1947 claim was made. If this potentiality was nominal, the claim would not have been accepted in the first place or would have been assigned a low value.

85 Report of the Minister of Housing and Local Government and the Secretary of State for Scotland under $\S 65(10)$ of the Town and Country Planning Act, 1954 and $\S 64(10)$ of the Town and Country Planning (Scotland) Act, 1954 (1960).

80 Once compensation is paid, the notice of payment which is filed in the local Land Charges Register has the effect of a hen on the property, inasmuch as the compensation will probably be repayable once "new development" is undertaken. Since the placing of a notice on file might impede the sale of the property, a landowner who ultimately expected to receive permission might hesitate before he claimed compensation. If he intends to develop himself, he will want to avoid the inconvemience of collection and repayment. To date, the amount of compensation recovered has been negligible. $I d$. at 4 . 
perhaps there is dissatisfaction with the ceiling that has been placed on compensation. The Ministry can make no estimate of potential demand under the statute, ${ }^{87}$ and the degree of public acceptance is conjectural.

\section{B. How the 1954 Act Works}

\section{Exclusions From Compensation}

The Green Belt policy can once more illustrate the operation of the 1954 statute. Ordinarily, no "new development" for urban uses is to be permitted in the Green Belt. Therefore, when an applicant seeks approval for urban development in the Green Belt and is refused, he can usually claim and receive compensation. ${ }^{88}$ There are exceptions to this general rule, lowever.

To place limits on the payment of compensation, the act contains several important exclusions. These function like the American police powereminent domain distinction to differentiate the reasonable from the unreasonable in land use regulation. As with section 19, however, the comparison must not be puslied too far. In the House of Commons an amendment to the exclusion section was rejected which would have precluded compensation if the planning refusal was "proper and reasonable and expedient having regard to the local circumstances." 80

Section 20 of the 1954 Act, reproduced in Appendix C, contains the exclusions from the payment of compensation. The most accepted explanation for the excluded categories is that compensation should not be payable when development would infringe on the principle of good neighborliness. ${ }^{.0}$

87 Id.at 5.

88 About $20 \%$ of the claims paid under the 1954 Act are reported to have been paid on the London Green Belt alone. Compared with § 19, the 1954 Act is the major vehiele for providing compensation for the Green Belt restrictions.

$80 \mathrm{H}$. C. Comm. Rept., note 48 supra, cols. 393-400. This was an opposition Labor amendment, and was rejected by the Minister of Housing on the ground that the local authorities and the Minister always make reasonable decisions.

Compare the exclusion provisions of the 1932 Act, Town and Country Planning Act, $1932,22 \& 23$ Geo. 5, c. 48 . They were similar to those contained in the 1954 Act except that the Minister was not to approve a local planning proposal excluding compensation unless he was satisfied that it was "proper and reasonable and expedient having regard to the local circumstances." 1932 Act, \$19(2) (i). The draftsmen of the 1954 Act adopted the suggestion of the Uthwatt Report, op. cit. supra note 76, that this qualifying clause was no longer needed because planning was now national in scope, plans having been required for the entire country under the 1947 Act. Notes on Clauses, suipra note 80, at 36. Nevertheless, a determination on reasonableness might still be in order. The Notes on Clauses recognize somewhat ambiguously that the content of the individual decision determines whether compensation is payable under the 1954 Act, and that this decision is local in effect. The discussion is not too helpful.

${ }^{00}$ Amendinent of Financial Provisions, CMD. No. 8699, at para. 35 (1952); Notes on Clauses, supra note 80, at 36: Land may not be exploited to the point where its use becomes detrimental to neighbors or to the conmumity. The Uthwatt Report, op. cit. supra note 76, 
Stated this way, their purpose relates closely to Professor Dunham's external cost rationale as a basis for proceeding under the police power and to the origin of American zoning in ordinances directed to incompatibility. In fact, however, the excluded refusals go beyond this formula. As the point was put to the Commons by the then Minister of Housing and Local Governnient, compensation was to be excluded when development was postponed, when development was permitted but limited or controlled in nature or scope, or when the development refused would have led to heavy community expenditure. ${ }^{91}$

No compensation is payable for the imposition of conditions relating to the number, location, or design of buildings, an exclusion which permits the imposition of density controls. This category fits the "good neighbor" rationale, since development at excessive densities would shift external costs to others in terms of noise, congestion, and other evils related to overcrowding. But sonie of the other categories are harder to classify. For example, no compensation is payable for a refusal of an application asking for a change in use, nor for a condition relating to use. This exclusion fits the "good neighbor" justification, to the extent that planning seeks to separate inconipatible uses. Yet "use" controls also impose absolute restrictions severely limiting freedom of choice for reasons not related to good neighborliness. The Green Belt policy is one example.

Some of the other exclusions are also difficult to justify on the good neighbor approach. No claim can be made for refusals of advertising applications. Planning authorities, it will be renienibered, nuay progran the order of residential and other development. The refusal of development for reasons of prematurity stenming fron programming proposals is not compensable. Nor is compensation payable when an application is rejected because of danger from flooding or subsidence. An advertising rejection, it was explained, can be based statutorily only on grounds of amenity and public safety, which are aspects of good neighborliness. ${ }^{92}$ The flooding and subsidence exclusion was justified because the granting of permission would lead to heavy public expenditure, apparently either for the renroval

at 94, 95, had criticized the similar exclusion provision in the 1932 Act. It found no basis in principle on which the excluded cases could be distinguished from those included. The planners' association had considered but then rejected a suggestion that restrictions protective of agricultural land or of amemity be non-compensable. Town PIANanng Institute, Aarendarent of Financiar, Provisions 3-5 (1953) (memorandum on the White Paper). See the discussion of this point in H.C. Comm. Rept., note 48 supra, cols. 383-86.

91525 H.C. DEB. (5th ser.) 55 (1954).

92 Notes on Clauses, supra note 80 , at 39 . In the House of Commons the exclusion was attributed to the fact that no development charge had been imposed on advertisements under the 1947 Act. H.C. Comm. Rept., note 48 supra, col. 392 . 
of buildings or for their protection. ${ }^{93}$ Finally, refusals for prematurity were made noncompensable because of the overriding necessity of preventing uneven development, and because development would ultimately be allowed in these cases and compensation would then have to be paid back. ${ }^{94}$

To date, there have been no important court decisions on the exclusion section, and only a few cases of any import in the Lands Tribunal. ${ }^{95}$ The discussion that follows is again partly speculative, partly the writer's impressions of Ministerial policy. It concentrates on the exclusion of compensation when development is refused because of prematurity, and when permission for a change of use is not granted. These exclusions are of particular interest because they are relevant to Green Belt and related controls. As they depart somewhat from the good neighbor rationale, their administration can help to illuminate further the purpose behind the exclusion section.

\section{The Prematurity Exclusion}

Programming proposals, especially as they relate to residential areas, can be of considerable importance to the Green Belt policy. Programmed residential areas may abut on the Green Belt, or may be contained in towns surrounded by the Green Belt. If development outstrips the program, housing pressures may weaken the effectiveness of the Green Belt policy. When development is refused for a programming reason the landowner may not be able to compel a purchase under section 19. Compensation is also excluded under the 1954 Planning Act. Section 20(3) provides that compensation is not payable if "one of the reasons stated for the refusal is that developnient ... would be premature by reference to ... (a) the order of priority, if any, indicated in the development plan... " 90 The weakness of this exclusion lies in the requirement that prematurity must be a "reason stated." This requirement has made the applicability of the exclusion depend upon the planning authority's formal use of prematurity as a ground for rejection of the application to develop.

One problem is that planning authorities are reluctant to use prematurity. Although the statute authorizes the showing of programming proposals on the development plan, the Ministry has been slow to accept

93525 H.C. DEB. (5th ser.) 55 (1954).

${ }^{94}$ H.C. Comm. Rept., supra note 48 , cols. 409-16; Notes on Clauses, supra note 80 , at 42 ; 533 H.C. DEB. (5th ser.) 849, 850 (1954).

95 The Tribunal was created by the Lands Tribunal Act, 1949, 12 \& 13 Geo. 6, c. 42. Appeals to the Tribunal from decisions denying compensation are authorized by the 1954 Act, $\S 27(2)$. As of November, 1959, only 24 appeals had been heard by the Tribunal, and 21 had been dismissed. Most of these cases had dealt with valuation problems. Lands Tribunal cascs are reported unofficially in the Planning and Compensation Reports.

96 Town and Country Planning Act, 1954, 2 \& 3 Eliz. 2, c. 72, \$ 20(3). (Emphasis added.) 
prematurity due to programming as the basis for rejection of a planning application unless a lack of water, sewage, or other services is the motivating reason. ${ }^{97}$ When planning authorities reject for prematurity, therefore, they usually refer to the absence of sewage or water services. Section $20(3)(b)$ authorizes an exclusion of compensation when the authority rejects because of an "existing deficiency in the provision of water supplies or sewage services."

An additional complicating element now enters the picture. A proviso to section 20(3) makes a refusal for prematurity on any basis compensable if a similar refusal lias been given on the same parcel within the past seven years. Although the proviso does not limit the authority's initial prematurity rejection to service deficiencies that will not be remedied within seven years, the Ministry lias so interpreted it. Legislative history, which talked about avoiding the constant payment and repayment of claims, supports this interpretation..$^{98}$ If the deficiency would last for more than seven years, Parliament apparently felt that the restriction is as good as permanent and should be compensable. ${ }^{99}$

One consequence of the concentration on service deficiencies as a reason for refusal in prematurity cases is to shift the emphasis to timing problems in the provision of services rather than the overriding public interest in phasing development. Informal inquiries will be directed to the planning authority, and the Ministry's judgment will be based on the imminency of the needed improvements. On the other hand, if the progranumed land happens to lie in a Green Belt the authority may give the Green Belt policy as an alternative ground. As the Green Belt restriction is assumed to be

97 In one of the counties adjacent to the County of London an application to build 24 semi-detached and three detached houses on land lying in the Green Belt was refused. This land was programmed for development in a later period of the development plan. If it were developed now public sewage services would be overtaxed. The Minister allowed the appeal against the planning authority. "Gas, water and electricity are immediately available and while he appreciates that the Council's sewage disposal works may be in danger of being overloaded he cannot accept this as a reason for dismissing the appeal." When one of the basic facilities has been unavailable, a different decision has been reached.

98 H.C. Comm. Rept., supra note 48, cols. 413, 414; Notes on Clauses, supra note 80, at 42. The proviso originally contamed a five-year limitation. It was extended because it was considered too short, and would have led to the payment of compensation on programming refusals when the deficiency would soon have been remedied and the compensation simply repaid.

09 The 1954 provisions partially supplement $\S 19$ of the 1947 law, as a purchase notice might not be confirmed in similar circumstances. However, the two compensation schemes are not mutually exclusive, and a purchase notice may be served under $\$ 19$ even though a claim has been paid under the 1954 Act. Double recovery is prevented by the fact that a payment under the $1954 \mathrm{law}$, which is liable to be repaid when development is undertaken, may serve to reduce pro tanto the market value of the property if it is forced to be acquired under § 19. Cf. Town and Country Planning Act, 1959, 7 \& 8 Eliz. 2, c. 53, § 17. 
permanent, not temporary, the prematurity exclusion will not be available. $^{100}$

Looseness in the statement of reasons for refusal and an over-literal approach to the statute combine further to reduce the scope of the prematurity exclusion. By circular, ${ }^{101}$ the Mimistry had asked planning authorities to give their reasons in full and to pay close attention to refusals for prematurity. Planning authorities do neither. To be on the safe side in case of an appeal, several refusal reasons are usually given. Because the local authority does not stand the cost of a 1954 Act claim, and because the press of business prevents any attention to the influence of language on the possibility of a claim, little care is used in drafting refusals.

In one case the local authority stated, in refusing permission, that "the use of this land for residential purposes would be premature." This language was held not to come within the exclusion of section $20(3)$; it was too far removed from the statutory language. Occasionally the Ministry will inquire informally of the local authority to ascertain the true reason for its refusal. But this can be done only when the authority "quotes the statute meaninglessly." Here they had not done so. Had the statute permitted the Ministry to refer to the general intent of the language of refusal, the exclusion might lave been operative. Instead, the statute required that the "reasons" be "stated." This the authority had not done.

The liandling of prematurity refusals that are plurased loosely and the handling of refusals based on service deficiencies present interesting contrasts in administrative interpretation. In the latter case the Ministry has looked to the policy of the statute to work out what it considers an equitable seven year limitation to determine when the absence of facilities is temporary and when it is permanent. But where the refusal is plirased loosely the Ministry has taken a literal approach and has refused in many cases to look behind the authority's expressed reasons for refusal to determine the real basis for its actions. Yet even this attitude does not always

100 In one case several refusal reasons were given, including Green Belt, no need for additional housing, protection of agricultural land, and prematurity. Because the development plan did not contain a formal programming proposal the claim was paid, with inferences that the prematurity exclusion could not be used in a Green Belt. In another case, however, the Green Belt reason was given in conjunction with danger of flooding. The second reason is also grounds for exclusion under the 1954 Act, and the use of the Green Belt reason did not prevent denial of compensation in this case. Perhaps the point is that prematurity is a tem. porary objection, while flooding is a "permanent" objection of coordinate importance with the Green Belt pohicy.

A recently reported change in Ministry policy would indicate that refusal reasons are now determined solely from the face of the planning decision, and that alternative Green Belt grounds will no longer prevent the prematurity exclusion from applying. The writer bas not been able to verify this change.

101 Ministry of Housing and Local Government Circular No. 40 (1955). 
prevent the Ministry from passing on the real basis of the planning decision when it considers the compensation claim. Witness the cases in which both a prematurity and a Green Belt reason have been given. ${ }^{102}$ However, the compensation decisions on exclusion do not always take account of the planning refusal that potentially triggers the exenuption from the act.

\section{The Change of Use Exclusion}

Section 20(1) (a) excludes compensation for "the refusal of permission for any development which consists of or includes the making of any material change in the use of any buildings or other land. ..."103 The use exclusion drives to the heart of planning controls, since it could be argued that the construction of any new building almost always involves a change in use. For example, the erection of houses on what was formerly Green Belt farm land involves a change of use from agricultural to residential. Such an interpretation finds support in the statutory exclusion of any developnent which "includes" a change in use. ${ }^{104}$ Under this approach, compensation would not be paid even when permission to build a new building is refused. ${ }^{105}$

A contrary construction, equally as extreme, would make the change of use exclusion mapplicable whenever building operations are involved. The definition section of the 1947 Act, which is applicable to the 1954 Act, defines the "use" of land to exclude "the carrying out of any building or

102 See the text at note 100 supra.

103 Town and Country Planning Act, 1954, 2 \& 3 Eliz. 2, c. 72, § 20(1)(a). (Emphasis added.)

104 An amendment to add this word was made in the House of Lords, on the point that it was impracticable to make a separation in a case which involved partly a change in land use and partly a change in building use. 189 H.L. DEB. (5th ser.) 885-94 (1954) (comment by Lord Chancellor). Much of the serious technical work on English legislation is done in the House of Lords, where many past Ministers sit as appointed peers.

105 This interpretation was advanced when the Lords amendments were discussed in the House of Commons. 533 H.C. DEB. (5th ser.) 839-41 (1954). Reference was made to $§ 18$ (3) of the 1947 Act. That section provides that a grant of permission "nay specify the purposes for which the building may be used; and if no purpose is so specified, the permission shall be construed as including permission to use the building for the purpose for which it is designed." For the opinion of the Solicitor-General on this interpretation see the discussion in note 110 infra.

In other parts of the planning acts the distinction between building operations on land and the use of land is not clearly made. For example, development is defined as "the making of any material change in the use of any buildings or other land." 1947 Act, $\$ 12$ (2). Then, for purposes of clarification, "the use as two or more separate dwellinghouses of any building previously used as a single dwellinghouse ..." is defined as a material change in use. 1947 Act, \$ 12 (3) (a). In the 1954 Act, § $16(5)(c)$, "new development" is defined in part as "both... the carrying out of operations and ... a change in use . . ." Cf. 1947 Act, § 33, authorizing the abatement of open land uses that injure amenity, apphed in Stephens v. Cuckfield Rural District Council, [1960] 2 All E.R. 716 (C.A.) (use of land adjacent to a building is not the use of "open" land). 
other operations. . . " "106 "Building operations," in turn, are defined to include rebuilding and structural additions or alterations. ${ }^{107}$ Those cases which have proved troublesome under the 1954 Act have involved use changes that have also required alterations in the building concerned. If these alterations fall within the Third Schedule to the 1947 Act, they will be excluded from compensation by the 1954 Act on the ground that they do not constitute "new development." 108 But if the changes are sufficiently extensive they will not fall within the Third Schedule and then the change of use exclusion must be applied. ${ }^{100}$ As the 1947 statute defines "use" to exclude building operations, one point of view would adopt the converse of this definition and hold that any application which contemplates a building operation excludes a change in use. To adopt this construction would practically eliminate the change of use exclusion, since almost every cliange in use involves some building operation.

These points were raised in the House of Commons, and the answer differentiated between proposed land uses and proposed building uses. A change in the use of land alone, or a cliange in the use of an existing building, would not be compensable if denied. But the denial of a change from a land use to a building use would not fall within the exclusion.110 This explanation still leaves the structural alteration denials out of account. These were discussed in the House of Lords, but a conclusive answer was not given. ${ }^{111}$

106 Town and Country Planning Act, 1947, $10 \& 11$ Geo. 6, c. 51, §119(1). At the same time, this section defines "land" to include a "building." This definition is ignored in the administration of the 1954 Act. It would make noncompensable the refusal of every application relating to a building. The interpretation section of the 1947 Act has been made applicable to the 1954 Act by $\S 69(2)$ of the latter statute.

107 Ibid.

108 Compensation under the 1954 Act is payable only when "new development" is refused. And "new development" is defined to exclude any development within the Third Schedule of the 1947 Act.

109 For example, the alteration may exceed the $10 \%$ tolerance permitted by the Third Schedule. Or it may involve a change in use classes, which is not permitted by the Third Schedule.

110 This was the opinion of the Solicitor-General on the interpretation advanced in note 105 supra. 533 H.C. DeB. (5th ser.) 842-44 (1954).

111 Remember that the exclusion had been amended to cover cases in which the application included a change in use, on the ground that the separation of the building operation and the use change was impracticable. See note 104 sktpra. Examples were given in debate of proposed changes in the use of a building which would have required substantial structural alterations. Since each alteration "included" a change in use, it was argued that a refusal would in each case be non-compensable. 189 H.L. DEB. (5th ser.) 886-92 (1954). In reply, the Lord Chancellor explained that all of these refusals would be compensable because they required building operations. $I d$. at $892-94$. But this explanation controverts his earlier statement that any refusal of an application inchuding a change in use would be non-compensable. If the Lord Chancellor had in mind the fact that all of the examples given required substantial structural alterations, his explanation would be in line with the dominant purpose test now adopted by the Ministry. 
The interpretive problems have not yet been resolved, although the current administrative interpretation takes a middle ground. In one case, for example, a house was to be converted to a shop. Several minor structural alterations were to be made, including a change in the size of a window. The application was refused and compensation was denied. Since the structural alterations were relatively minor, the change of use exclusion was applied because the dominant purpose of the application was the adaptation of an old building to a new use. In another case the conversion of a disused cliapel to a gasoline filling station was proposed. In this instance the change of use exclusion was not applied because the changes required were so extensive that a new building would have been substituted for the old. From these cases it appears that a dominant purpose approacl has prevailed over the second extreme view outlined above, whicl would have paid compensation whenever any building operations were involved in the change of use. ${ }^{112}$

Cases of the type that have been described may appear borderline, but they are more common in England than in America because the land shortage leads to the intensive re-utilization of existing structures and scrap pieces of land. Conceptually, the change of use exclusion points to a structural difficulty in planning law. Material wealth now lies mainly in the improvements and not in the land. This distribution reverses the historical position, which gave land prominence, and which heavily influenced the development of property law. Like property law, planning law has had to take account of the modern reality. American courts liave been seen to make this differentiation when deahing with nonconforming uses. When vacant land is involved, the courts liave had little difficulty in applymg zoning regulations retroactively. For the most part, they liave not permitted immediate retroactive application when there was a substantial investment in buildings. Borderline cases have presented difficulties. ${ }^{113}$ Both the English statutory and the American judicial approach reflect the commonsense attitude that the owner's investment in capital structure is the critical issue in the compensation problem.

A final weakness in the statutory framework reduces the effectiveness of the change of use exclusion. An applicant who is refused permission for a change of use can always re-apply for the construction of a building. When this application is refused he can then secure compensation without worrying about the change of use exclusion. The only decided case on the

112 Compensation has also been denied when the refused application called for the construction of a recreation ground which included minor structures. In another case the laying of paving for a parking lot was not considered to be a building operation.

${ }_{113}$ Cf. People v. Miller, 304 N.Y. 105, 106 N.E.2d 34 (1952) (zoning ordinance may be apglied retroactively to keeping of pigeons; use not substantial). 
point seems to indicate that the applicant's intent will not be investigated. ${ }^{114}$ In several well-known cases, golf clubs in the Green Belt have applied for industrial development, and when refused have duly collected their claims under the 1954 Act. Possible valuation difficulties in instances like this have been eliminated because compensation is pegged to 1947 values, which are a fraction of current prices.

Section $20(2)(d)$, which is related to the change of use exclusion, excludes compensation when planning permission is given subject to any condition relating to "the use of any buildings or other land. . . .110 This exclusion has unexpected applications because English planning attempts to be selective among competing uses for reasons not related to compatibility. In a Green Belt, which is supposed to be restricted to agricultural uses, a house may be allowed if it is to be built for an agricultural worker, but the same house may be denied if it is to be built for a London commuter. The planning authority may play it safe and decide to impose a condition limiting the house to occupation by an agricultural worker. Is this a condition relating to use for which compensation would be denied under the statute? Just as easily, it could be viewed as a condition limiting the occupancy of a building, and thus unrelated either to the use of the land or the building. Arguably, the character of a residential use does not depend on the vocation of the person who enjoys it. Under this approach, the condition would be compensable. The only case which touches on the problem approaches it from another perspective, but lends support to a contrary interpretation. ${ }^{116}$

\section{An Evaluation of the 1954 Compensation Scheme}

So far, experience with the prematurity and change of use exclusions has been disappointing. Both exclusions were considered vital to the func-

114 Overland v. Minister of Housing and Local Government, 8 Plan. \& Comp. R. 389 (Lands Tribunal 1957): The applicant made an outline application for an industrial use. An outline application, as distinguished from a full application, only gives the developer's scheme in general and does not include full details and binding plans. It is authorized by the regulations as a method of ascertaining the sense of the planning authority witbout going to the expense of full plans. But the regulations limit the outline application to building operations. [1950] 2 STAT. INSTR. 1056 (No. 728, § 5(1)). For this reason, the Tribunal ruled that the change of use exclusion was inapplicable. It leld that, under the circumstances, the actual use to which the applicant would bave put the land was immaterial.

115 Town and Country Planning Act, 1954, 2 \& 3 Eliz. 2, c. 72, § 20(2)(d).

116 Francis v. Minister of Housing and Local Gov't, 10 Plan. \& Comp. R. 151 (Lands Tribunal 1959): Permission for a residence was given subject to the condition that occupancy be restricted to nembers of the agricultural population. This condition is sometimes used to keep suburban commuters out of the Green Belt. Its validity was upheld in Fawcett Properties, Ltd. v. Bucks County Council, [1960] 3 All. E.R. 503 (H.L.). In Francis the Tribunal leld that the imposition of the condition did not require the payment of compensation. Section 21(3) of the 1954 Act excludes compensation in any case when pernission is given 
tioning of the statute. ${ }^{117}$ Parliament also intended that these as well as other exclusions should operate automatically, with a minimum exercise of administrative discretion. ${ }^{118}$ These hopes lave been disappointed. Even though the exclusions are carefully defined, the closeness of the statutory language has simply aggravated the problem of construction, and weaknesses in drafting have reduced the effectiveness of these sections.

As compared with section 19, the basic characteristic of all the 1954 provisions is their concentration on the nature of the restriction imposed rather than on the extent of the use that remains. Thus a refusal because of danger from flooding would not be compensable under the 1954 Act, although a section 19 notice would be confirmed if the land were not capable of a reasonably beneficial use in its existing state.

But compensation under the 1954 planning act is more expedient than it is logical. The exclusion of compensation in the interests of good neighborliness goes further than the nuisance-zoning counterpart in the American system, and in any event not all of the exclusions fit the good neighbor rationale. In some cases the exclusion from compensation fits better the English notion of what is a proper aim in planning. For example, the prenaturity exclusion is explainable primarily by the English abhorrence of ribbon and sporadic development in the countryside, which programming in development plans is supposed to prevent.

Two limitations on the fundamentals of the 1954 scheme help to simplify its administration but at the same time frustrate its purpose. Since the applicant's intent is not determinative under the act, he is often in a position to apply for planning permission in a way that will attract a compensable refusal and avoid the impact of the exclusion section. There is no crusading fervor in the Ministry in the application of the exclusion provisions. Equally as important is the limitation of payment under the 1954 Act to the 1947 claim. Only the landowner who is refused planning permission, or who is granted permission subject to onerous and non-compensable conditions, is prevented from realizing the market value of his property. If he is to get compensation at market value, his only recourse is a section 19 notice, which may not be confirmed. A drastic inflation in land values since 1947 forces the claimant to take a substantial write-down on

for residential use. The Tribunal held that the condition does not make the permitted use any the less residential.

117 The prematurity exclusion was related to the important objective of preventing sporadic development. Notes on Clauses, supra note 80, at 42. In the House of Commons, the Minister of Housing had pointed out that a change of use might have to be resisted in the interests of good neighborliness. For example, a business use might have been proposed in a residential district. 525 H.C. DeB. (5th ser.) 55, 56 (1954).

118 Notes on Clauses, supra note 80 at 37,38 , following the recommendations of the Uthwatt Report, op. cit. supra note 76, at para. 237. But see H.C. Comm. Rept., note 48 supra, cols. 423-25 (exclusion clause does not leave enough discretion to local authority). 
his loss if he proceeds under the 1954 Act. Whether this anomaly can permanently endure is open to question. ${ }^{119}$

\section{CONCLUSION}

\section{A. Solving the Compensation Riddle}

Much of the difficulty in allocating benefits and burdens in land use planning hes in the accident of disparate ownership. Since the ownership pattern bears no logical relationship to the planning decision, the burden of planning restrictions will be unevenly and fortuitously distributed. At the same time, and just as fortuitously, many landowners will find that they have benefited from planning decisions that confer an unearned increment of value. Short of nationalization, a solution to the problem of benefit and burden in land planning will have to begin with a redefinition of the relationship between the land owner and the community. Historically, the private ownership of land in relatively small parcels has forced the American community into a one-to-one relationship with the landowner. Throughout planning law, the tendency is to view the restriction to a considerable extent from the point of view of the objector and the effect on his parcel. One example is the spot zoning amendment. ${ }^{120}$ Another is the variance granted because of unnecessary hardship resulting from the effect of the restriction on a single plot of land. ${ }^{221}$

As American planning moves in the direction of the English to restrict more severely the developer's freedom of choice, two courses are open. The law can take cognizance of individual circumstances and compensate fully when limitations are imposed. For example, suggestions have been made that open land in the countryside be publicly acquired so that it can be preserved from urban developinent. ${ }^{122}$ Or the law can expand the concept

119 As compared with the landowner who is refused permission, the landowner whose land is compulsorily acquired must now receive market value under the 1959 Act, \& I (1). Of course, if he receives permission, he is able to realize the full market value of his property. Under the 1932 Act, compensation was paid in full for planning restrictions. This requirement is thought by most observers to have been responsible for the timidity and lack of planning that prevailed in the interwar period. If compensation had to be paid at market value for Green Belt restrictions, for example, how long could this policy be held?

120 See Langguth v. Village of Mount Prospect, 5 Ill.2d 49, 124 N.E.2d 879 (1955) (comparative weighing of public benefit and individual hardship to the advantage of the property owner).

121 Compare the appellate and supreme court opinions in Nelson v. Board of Zoning Appeals, 158 N.E.2d 167 (Ind. App.), rev'd, 162 N.E.2d 449 (Ind. 1959).

122 An attempt could be made to avoid the excessive burden of full compensation by condemning less than the fee. Only a conservation easement would be acquired, which would prevent the landowner from developing open land for urban purposes by transferring this 
of community well-being which is essential to a finding of constitutional validity under the police power.

If the second course is taken, a restriction on development which may appear unwarranted in an individual case would gain meaning when placed in a wider perspective. ${ }^{123}$ Precedent for this approach can be found in urban renewal laws. They permit the condemnation of adequate and well-maintained property in what is generally a slum area, and the courts have sustained these takings to protect the comprehensiveness of the slum clearance program as an entity. ${ }^{124}$ Similarly, the planning authority ought to be able to characterize an open space area as a Green Belt to be kept clear of residential building. Within that area, the demal without full compensation of permission to build houses on property that is ready and suited for development could be justified as contributing to the total scheme. For example, English planning authorities often prevent even the "imfilling" of a vacant plot in a row of houses if the houses stand in the open country, and if infilling of the nucleus will ultimately endanger the basic Green Belt policy. ${ }^{125}$

At this point, however, American coinpensation law presents a mutually exclusive choice. In the urban renewal example given above, the non-slum property owner whose property was taken was paid at market value under the eminent domain power. A Green Belt program carried out under planning powers offers him no compensation at all. In these circumstances, the American dualism of police power (no compensation) -eininent domain (full coinpensation) breaks down. Planning restrictions which severely

incremental land use to the state or to the municipality. WHXTE, SECURING OPEN SPACE FOR Urban America: Conservation Easemients 30-36 (1959). See Cal. Gov't Code, \$\$ 6950-54 (Supp. 1960). This suggestion resembles the original pattern of the 1947 English law, which nationalized development value. See the discussion in the text at note 36 supra.

123 For similar suggested reforms of just compensation requirements as they operate in an urban environment see Dunham, From Rural Enclosure to Re-Enclosure of Urban Land, 35 N.Y.U.L. REv. 1238 (1960).

124 See Berman v. Parker, 348 U.S. 26 (1954); Velishka v. City of Nashau, 99 N.H. 161, 106 A.2d 571 (1954); David Jeffery Co. v. City of Milwaukee, 267 Wis. 559, 66 N.W.2d 362 (1954).

125 The Green Belt concept creates a new kind of nonconformity. As the Green Belt ring is intended for agricultural and "open" recreational and related uses, a small hamlet or village within the Green Belt may be nonconforming in relation to the total scheme. On analogy to the American treatment of nonconforming uses in zoning, the extension of the hamlet could be prohibited altogether. For planning appeals to the Minister in which this position was taken in one county in the London Green Belt see 1960 J. PLAN. \& Prop. L. 798 (second case); 1960 J. Plan. \& Prop. L. 798 (first case); 1960 J. Plan. \& Prop. L. 740 (second case). However, the Minister has attempted an ambiguous compromise by authorizing the "infilling" and "rounding-off" of existing commumities within the Green Belt. Minister of Housing and Local Government Circular No. 42, § 6 (1955). This dispensation has not been consistently applied, and there are indications that too frequent applications of the exceptions may be harming the Green Belt policy. Mandelker, Planning Appeals and the Adjudication of Policy, 1960 PuBLIC LAW 256. 
limit freedom of choice might not be fully sustainable under the police power. Yet full compensation under the eminent domain power is neither necessary nor practicable. The cost of acquiring large areas sterilized as Green Belt would alone be prohibitive. ${ }^{126}$ No mechanism exists for achieving an intermediate solution.

One answer would be a program of partial compensation related to a program of partial collection of betterment. This approach would place the interests of the individual property owner in the framework of a community-wide view of planning law. It would also accommodate planning policy to the incidence of taxes on real estate. Through the allocation of fiscal burdens, taxation already achieves an ad hoc adjustment of compensation and betterment. For example, the lot owner in a new subdivision already pays in his purchase price for street and other improvements that are handled by special assessment. Development charges, at first fixed at fairly low levels, ${ }^{127}$ would recoup for the community some of the additional value which it has bestowed on the developer through land use regulations. ${ }^{128}$ Especially as American planners move toward acceptance of the Green Belt idea, which would see large segments of peripheral land restricted from urban use, the value of the remaining land that is earmarked

120 American proposals to purchase Green Belt land by acquiring either a fee simple interest or a conservation easement do not appear too hopeful if the English experience is consulted. Under the Green Belt (London and Home Counties) Act, 1938, 1 \& 2 Geo. 6, c. 93, (Local and Private Acts), the counties adjacent to the County of London were enabled to acquire land for Green Belt purposes. Up to $50 \%$ of the cost of acquisition could be contributed by the London County Council. Once purchased, the use of the land could not be changed without the Minister's consent. Although substantial acreages were purchased under this Act, prohibitive costs ultimately led to the termination of the program.

${ }^{127}$ Municipalities in some states lave experimented with lot fees in connection with subdivision approvals to defray the cost of improvements that are not readily charged under special assessment procedures. Most of the fees have been fairly nominal. They have been applied to the acquisition of parks, or to the construction of drainage facilities that indirectly benefit the subdivision but which are located at some distance from it. In one case the municipality applied the fee to the police, fire, and related expense of protecting new residential subdivisions while they were being built. Judicial reaction has been mixed. Kelber v. City of Upland, 155 Cal. App. 2d 631, 318 P.2d 561 (1957); Merrelli v. City of St. Clair Shores, 355 Mich. 575, 96 N.W.2d 144 (1959); Gulest Associates, Inc. v. Town of Newburgh, 25 Misc. 2d 1004, 209 N.Y.S.2d 729 (Sup. Ct. 1960); Haugen v. Gleason, 359 P.2d 108 (Ore. 1961); Note, 1961. Wrs. L. Rev. 310. See CaL. Bus. \& Prof. Code $\$ 11543.5$ (Supp. 1960): Authorizes imposition of lot fees as a condition of approving a subdivision map, the fees to be paid into a fund for the construction of planned local drainage facilities.

128 Cf. New York State Thruway Authority v. Ashley Motor Court, Inc., 12 App. Div. 2d 223, 210 N.Y.S.2d 193 (1961). The court held constitutional a statute which prohibits the erection of an advertising sign within 500 feet of the Thruway unless a special permit has been given by the Authority. The court said in part:

"Tle public benefit which flows from such regulations is sufficient compensation for whatever restriction is imposed upon the owner of the adjoining private property . . . The purpose of building a highway is not to increase the monetary value of the adjoining property." 12 App. Div.2d 231, 210 N.Y.S.2d at 201. 
for development would be increased that much more. Through development charges the individual lot owner would contribute to those community services, such as schools, that are made necessary by his development and that are not easily handled by special assessment procedures.

Provisions for partial rather than for full compensation would start with the landowner's position as a member of the community. Although he loses on the restriction of his property, he gains as a member of the community from the benefits that the restriction confers. A Green Belt policy may prevent a farmer from sprouting suburban houses on his acres, but it will also maintain open and recreational space that the farmer will be able to enjoy. Healthy planning contributes to a healthy community base and thus, indirectly, to a healthy tax base. Other benefits could be instanced. Consistent with constitutional compensation requirements, the justification of a Green Belt scheme could be supported in part under the police power. The excess of the restriction over the benefit deemed to be conferred on an individual property would be compensable. ${ }^{129}$

Adjustments in the tax structure would contribute further to the equity of the compensation arrangements. In England, farm land and buildings have been exempted from tax. In this country farms are subject to the property tax, with results which may be inequitable. For example, farm land which lies close to advancing suburban areas is often assessed at the urban rather than the farm use, which makes the continuance of farming very difficult. Fringe land is then forced into subdivision at a rate which is perhaps faster than is required. As a step toward a better adjustment of tax incidence, assessment or collection procedures could provide for the forgiveness of all or most of the taxes falling due on land restricted from development. ${ }^{130}$ The landowner would then no longer be charged by the

129 Precedent for this approach can be found in the New York flight hazard law, N.Y. MUNrc. LAw $\S \S 355,356$. The law authorizes the removal of structures and other flight hazards that he within 3000 feet of an airport. Section 356 (c) indicates that removal is to be accomplished "to the extent legally possible under ... the police power without coinpensation ...." Section 356 (d) states that where the regulations "would prove so unreasonable as in fact to constitute a taking of the property affected," $\S 355$ authorizes the acquisition of the fee or of a lesser interest in the property.

130 Some states have experimented with differential assessment techniques which would assess farm land on the nrban periphery at its value for farm use, and which would not reflect the increased value resulting fron proximity to developing residential areas. These experiments have met with varying judicial success. Wershow, Agricultural Zoning in FloridaIts Implications and Problems, 13 U. FiA. L. Rev. 479 (1960). They have sometimes been invalidated under constitutional uniformity of taxation clauses. An alternative is a total or partial, permanent or temporary exemption. Legislation introduced in the 1961 session of the Indiana General Assembly (S.B. 264) would have granted "open" land designated as a water storage, flood plain, industrial, or recreational district as much as a $55 \%$ deferral froin taxes, to be collected when the land was privately developed or acquired for the designated public purpose. See also Stegex, The Law of Open Space 43-61 (1960). 
community for holding back on the development of his land in accordance with planning policy.

\section{B. Adapting the English Scheme}

As it presently stands, the English sclieme for adjusting compensation and betterment is inconiplete. The failure of the postwar attenipt to collect development charges has blocked even suggestions for the partial collection of betterment. However, section 19 of the 1947 Act and the compensation sections of the 1954 Act come close to providing a workable compromise for the partial compensation of the losses resulting from planning restrictions. Perhaps the guiding thought of these provisions is the idea that substantial deprivations must be compensated but insubstantial deprivations must be accepted. This goal is accomplished by refusing to take prospective development into account under section 19 , and by the exclusion provisions and the limitation on the amount of the claim under the 1954 Act.

Rough edges and inconsistencies in the theory of the English law still need adjustment. For example, a refusal of a change in use may be more serious a deprivation than a refusal to construct a minor structure, but the first refusal would not be compensated under the 1954 Act while the second would. More basically, section 19 of the 1947 Act concentrates on the reasonableness of the use of the property, while the 1954 exclusory provisions concentrate on the reasonableness of the restrictions themselves. Perhaps an adjustment of the compensation problem should take account of both factors. "Positive" zoning in America differs from previous practice both in its greater restriction on the freedoin of the developer, and in its wider definition of community well-being. The designation of those planning restrictions which iniply a serious restriction of the developer's freedom of choice should be possible without borrowing the difficult constructional problems that would be raised by a statute drafted along the lines of section 19 and the exclusion provisions of the 1954 Act.

Perhaps the biggest obstacle to the adaptation of the English scheme arises from differences in administrative techmique. The American states do not have the central administrative arrangements which would permit the payment of compensation claims on a statewide basis. American adaptation would have to proceed through a modification of the eninent domain machinery. One possibility is an extension of the technique of reverse eminent donrain along the lines of section 19, to compel public acquisition in cases of serious restriction resulting from the use of planning powers. Precedent for this practice already exists in American statutes permitting the landowner to conipel the acquisition of his property when it has been 
designated for highway uses, and the highway authority has not moved to acquire the parcel after a stated period of time. ${ }^{131}$

When the notice to acquire is served, the planning authority would be given the option of buying the parcel or of acquiring an easement of development which would restrict the use of the land in accordance with the planning scheme. In the latter event, as under the 1954 English statute, the landowner would collect compensation and yet retain title to his property. Tests similar to those employed in the English 1954 Act would be used to determine the extent of the interest which ought to be acquired and to indicate whether compensation ought to be excluded altogether. If conipensation is indicated, the award would be reduced by permitting the planning authority to offset against compensation costs a sum equal to the gain that the landowner derives as a member of the community benefited by the restrictions to which he objects. ${ }^{132}$ In other words, police power justification would partially offset the cost of compensation.

These proposals are meant to be suggestive only. And the solution they advance is a rough and approximate one. But to paraphrase Justice Holmes, the task of the law is the drawing of lines. In so doing we may commit errors of judgment in the accommodation of principle, but perhaps this is the best that the law can afford. ${ }^{133}$

131 E.g., IND. ANN. STAT. § 36-2955 (Supp. 1961) (ninety days after service of notice by landowner). Consider also those authorities that permit a single recovery in one suit for all the damages flowing from a continuing nuisance, or trespass. RESTATEMENT, TORTS $§ 930$ (1939). 132 If highway condemnation experience is any guide, then practical difficulties in the application of a benefit offset test cannot be brushed aside. Heaney, Varuation of Property FOR HIGHWAYs UNDER EMIINENT Domain 33-36, 78 (1960). However, the principle is worth a try if it has merit.

133 Schlesinger v. Wisconsin, 270 U.S. 230, 241 (1926) (dissenting opinion). 


\title{
APPENDIX A \\ TOWN AND COUNTRY PLANNING ACT, 1947, THIRD SCHEDULE. EXCEPTED CLASSES OF DEVELOPMENT.
}

\author{
PART I. \\ Developarent Included in Existing Use for Purposes Other Than \\ COMPPENSATION UNDER S. 20
}

1. The rebuilding, as often as occasion may require, of any building which was in existence on the appointed day and of any building which was in existence before that day but has been destroyed or demolished since the seventh day of January, nineteen hundred and thirty-seven (including the making good of war damage which has been sustamed by any such building) and of any other building in existence at a material date, being $a$ building erected after the $a p$ pointed day, so long as the cubic content of the original building is not exceeded in the case of a dwelling-house, by inore than one-tenth or seventeen hundred and fifty cubic feet, whichever is the greater, and in any other case by more than one-tenth.

2. The use as two or more separate dwelling-houses of any building which at a material date was used as a single dwelling-house.

PART II.

\section{Developarent Included in ExISTifg Use for ALl PURPoses}

3. The enlargement, improvement or other alteration, as often as occasion may require, of any such building as is mentioned in paragraph 1 of this Schedule, or any building substituted therefore by the carrying out of any such operations as are mentioned in that paragraph, so long as the cubic content of the original building is not increased or exceeded, in the case of a dwelling-house, by more than one-tenth or seventeen hundred and fifty cubic feet, whichever is the greater, and in any other case by more than one-tenth.

4. The carrying out, on land which was used for the purposes of agriculture or forestry at a material date, of any building or other operations required for the purposes of that use, other than operations for the erection, enlargement, improvement or alteration of dwellinghouses or of buildings used for the purposes of market gardens, nursery grounds or tinber yards or for other purposes not connected with general farming operations or with the cultivation or felling of trees.

5. [The winning and working on agricultural land of minerals required for that use.]

6. In the case of a building or other land which at a material date was used for a purpose falling within any general class specified in an order made by the Minister for the purposes of this paragraph, or which, being unoccupied on and at all times since the appointed day, was last used (otherwise than before the seventh day of January, nineteen hundred and thirtyseven) for any such purpose, the use of that building or land for any other purpose falling within the same general class.

7. [Permits ten per cent extension of partial use of land or buildings.]

8. [Deposit of waste in connection with mineral working.]

9. [Appointed day ineans the date the 1947 Act took effect, and material date is defined as any other day upon which the provisions of the Schedule take effect in a particular case. As a result the Schedule is apphicable to events occurring after the effective date of the 1947 Act.]

10. [If planning condition has been imposed limiting duration of use of buildings or land, Schedule is to apply only for duration of that period. Applies only to conditions inposed since the effective date of the 1947 Act.]

[NoTE: The italized words indicate either additions or anendinents to the Third Schedule by Town and Country Planning Act, 1954, 2 \& 3 Eliz. 2, c. 72, \& 71; Schedule VII, \& 4. Sections 9 and 10 were added by the 1954 amendinents.] 


\section{APPENDIX B}

\section{TOWN AND COUNTRY PLANNING ACT, 1947, SECTION 19}

\section{Obxigation to Purchase Land on Refusal of Permission dn Certand Cases}

19.-(1) Where permission to develop any land is refused, whether by the local planning authority or by the Minister, on an application in that behalf made under this Part of this Act, or is granted by that authority or by the Minister subject to conditions, then if any owner of the land claims-

(a) that the land has become incapable of reasonably beneficial use in its existing state; and

(b) in a case where permission to develop the land was granted as aforesaid subject to conditions, that the land cannot be rendered capable of reasonably beneficial use by the carrying out of the permitted development in accordance with those conditions;

(c) in any case, that the land cannot be rendered capable of reasonably beneficial use by the carrying out of any other development for which permission has been or is deemed to be granted under this Part of this Act, or for which the local planning authority or the Minister have undertaken to grant such permission,

he may, within the time and in the manner prescribed by regulations made under this Act, serve on the council of the county borough or county district in which the land is situated a notice (hereinafter referred to as a "purchase notice") requiring that council to purchase his interest in the land in accordance with the provisions of this section.

(1A) [Council may accept or refuse to accept the notice. If they refuse to accept, the notice is referred to the Minister with a statement of their reasons for refusal.]

$\cdots$

(2) ... [T]he Minister shall, if he is satisfied that the conditions specified in paragraphs (a) to (c) of subsection (1) of this section are fulfilled, confirm the notice, and thereupon the council shall be deemed to be authorized to acquire the interest of the owner compulsorily ....

Provided that-

(a) if it appears to the Minister to be expedient so to do, he may, in heu of confirming the purchase notice, grant permission for the development in respect of which the application was made or, where permission for that development was granted subject to conditions, revoke or amend those conditions so far as appears to him to be required in order to enable the land to be rendered capable of reasonably beneficial use by the carrying out of that development;

(b) if it appcars to the Minister that the land, or any part of the land, could be rendered capable of reasonably beneficial use within a reasonable time by the carrying out of any other development for which permission ought to be granted, he may, in heu of confirming the notice, or in heu of confirming it so far as it relates to that part of the land, as the case may be, direct that such permission shall be so granted in the event of an application being made in that behalf;

(c) [the Mmister may substitute another authority other than the authority naned in the notice].

(2A) Where, for the purpose of determining whether the conditions specified in paragraphs (a) to $(c)$ of subsection (1) of this section are fulfilled in relation to any land, any question arises as to what is or would in any particular circumstances be a reasonably beneficial use of that land, then, in determining that question for that purpose, no account shall be taken of any prospective use of that land which would involve the carrying out of development of any class not specified in the Third Schedule to this Act.

(3) $-(7)$ [The remaining subsections provide for a hearing on the request of interested parties, provide that a notice is deemed confirmed by the Minister if no action is taken within six months, and contain minor clarifying provisos.]

[NoTE: Section IA was added by the Town and Country Planming Act, 1959, 7 \& 8 Eliz. 2, c. 53, $\S 35(1)$. The italicized words in section 2 are an amendment by Schedule VII of the 1959 Act. Section 2A was first added by the Town and Country Planning Act, 1954, 2 \& 3 Eliz. 2, c. 72, $\S 70(1)$. It was amended by the 1959 Act, $\$ 35(2) .1$ 


\section{APPENDIX C}

\section{TOWN AND COUNTRY PLANNING ACT, 1954, SECTION 20}

\section{EXCLUSTONS FROM COMPENSATION}

20.-(1) Compensation under this Part of this Act shall not be payable-

(a) in respect of the refusal of permission for any development which consists of or mcludes the making of any material change in the use of any. buildings or other land; or

(b) in respect of any decision made on an apphication in pursuance of regulations under section thirty-one of the principal Act for consent to the display of advertisements.

(2) Compensation under this Part of this Act shall not be payable in respect of the impo- sition, on the granting of permission to develop land, of any condition relating to-

(a) the number or disposition of buildings on any land;

(b) the dimensions, design, structure or external appearance of any building, or the materials to be used in its construction;

(c) the manner in which any land is to be laid out for the purposes of the development, imcluding the provision of facilities for the parking, loading, unloading or fuelling of vehicles on the land;

(d) the use of any buildings or other land; or

(e) the location or design of any means of access to a highway, or the materials to be used in the construction thereof,

or in respect of any condition subject to which permission is granted for the winning and working of minerals.

(3) Compensation under this Part of this Act shall not be payable in respect of the refusal .of permission to develop land if the reason or one of the reasons stated for the refusal is that development of the kind proposed would be premature by reference to either or both of the following matters, that is to say-

(a) the order of priority, if any, indicated in the development plan for the area in which the land is situated for development in that area;

(b) any existing deficiency in the provision of water supphes or sewerage services, and the period within which any such deficiency may reasonably be expected to be made good:

Provided that this subsection shall not apply if the planning decision refusing the permission is made on an application made more than seven years after the date of a previous planning decision, whereby permission to develop the same land was refused for the same reason, or for reasons which included the same reason.

(4) Compensation under this Part of this Act shall not be payable in respect of the refusal of permission to develop land if the reason or one of the reasons stated for the refusal is that the land is uusuitable for the proposed development on account of its hability to flooding or to subsidence.

(5) In subsection (3) of this section, the reference to the development plan for the area in which the land is situated is a reference to the development plan for that area as approved by the Minister or, if the plan so approved has been amended by the Minister, to that plan as so amended.

(6) For the purposes of this section, a planning decision whereby permission to develop land is granted subject to a condition prohibiting devclopment of a specified part of that laud shall be treated as a decision refusing the permission as respects that part of the land. road.

(7) In this section the expression "means of access to a highway" does not include a service 